\title{
النظام القانوني لتوثيق عقد الزواج إلكترونياً
}

\author{
بجاث مفرم الى مؤَر \\ الجوانب القانونيتّوالاقتصاديت للذكاء الاصطناعي \\ وتكنولوجيا المعلومات \\ rrr \\ كليتة الحقوق- جامعت المنصورة مايو
}

shel

د/ أشرف محمد إسماعيل

$$
\text { دكتوراه في القانون المدني }
$$

كليتالحقوق - جامعت عين شمس 


\section{مقدمهة}

إن التطور الهائل في تكنولوجيا المطلومـات والاتصالات والذي تشهده البشرية في العصر الحديث أدى إلى تغيير أنمـاط السلوك الاجتمـاعي ، ونتيجة لهذا التطور المتسارع خَّق عالماً جديداً يعتمد على الثبكات الرقمية التي تعمل على نقل المعلومـات

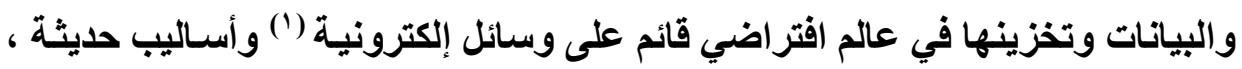
حيث أصبحت الثعوب تتحاور فيما بينها دون قيود أو حواجز ، وانتقل ذلك تدريجياً إلى فئل كافة العقود المبرمسة من قبل الأفراد ، ومنها عقد الزواج الذي يعتبر فاتحة الأسرة وأساس لتكوين أجيال في الإطار الصحيح ، إذ قلست علاقة الزواج في كل المجتمعات الترات

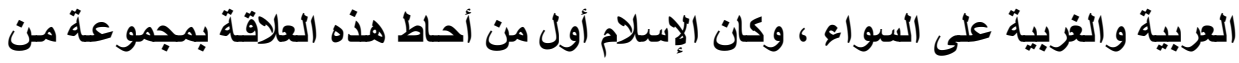

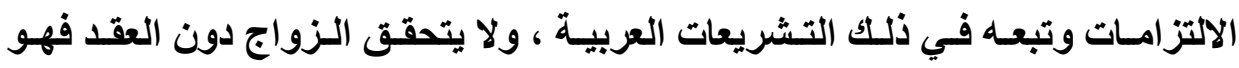
الميثاق الغليظ الذي جطه الله عز وجل الوسيلة الوحيدة التي يجوز فيها معاشرة كلا

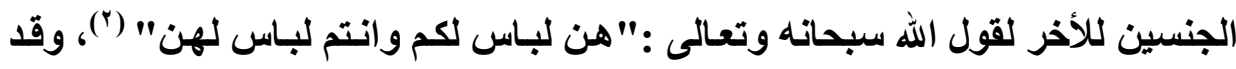

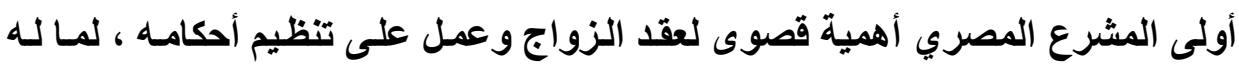

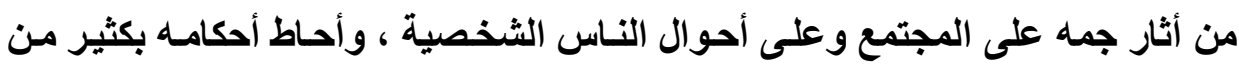

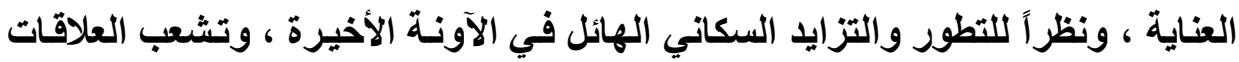

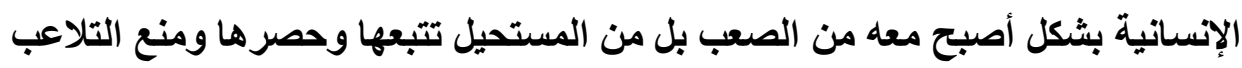

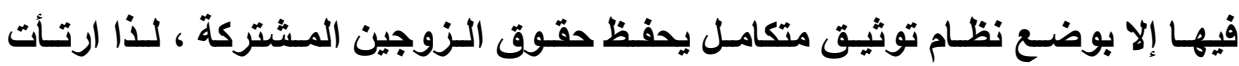

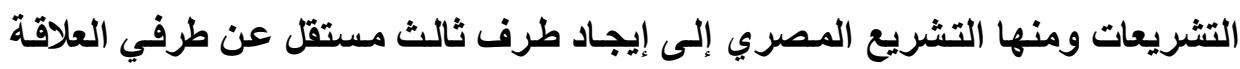

(1) إبراهيم السوقي أبو الليل: الجوانب القانونية للتعاملات الإكترونية ، دار النهضة العربية بالقاهرة

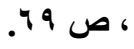

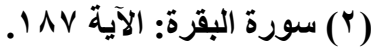




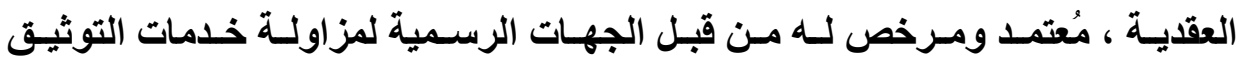
والتصديق الإكتروني (') المعتمدة وفقاً للتشريع المعمول به ، بحيث يُعول على خدماتـه من أجل تسهيل الإجراءات والتيقن من إرادة كل طرف ومدى صحتها ونسبتها إلى من صدرت منـه ، وبُعدها عن الغش أو الاحتيـال ، والتيقن مـن سـلامة البيانـات المتصلة بالمحرر الإكترونـي من أي تعديل أو تحريف أو تغيير بطريقة تقتية أمنـة عبر شبكة الإنترنت درعاً للنزاعات.

وتظهر أهمية تلك الدراسة في التعرف على الدور الذي تقوم بـه جهة التوثيق الإكتروني في إثبات العلاقة الزوجية وتقتين العقوق المشتركة بين الطرفين ، وذلك باعتماد هذه الجهة كوسيلة لتعيين الأطراف المتعاقدة وتحديد القواعد والنظم الملائمـة فيما يخص المعايير التي ينبفي أن يستوفيها ، لتثبت الثقة للى المتعاملين ، وتؤمن عملية التبادل المعلوماتي ، وذلك بما تضعه تحت أيديها من تقنيات كالتشفير المتماثل وغير المتماثل ، والتي تضمن بـه تأمين ونسبة البياتـات والمعلومـات إلى صساحبها ، وعدم إحداث أي تعديل أو تغيير أو تحريف في مضمونها ، وإزاء هذا التطور والتغيير الكبيرين الحاصلين في مجـال تقتيـات المعلومـات ، والمتغيرات الحاصـلة في أثـكال

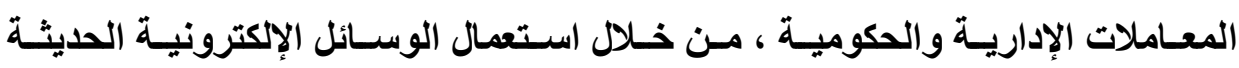
والثبكات المعلوماتية ، ظهر جه تثريعي قانوني كبير وواضـح على الصعيد الدولي والوطني ، وذلكك بـقرار وإصدار التشريعات والقوانين وسن الإرشـادات والتوجيهات المنظمة في هذا المجال ، حيث صدر قانوني الأونيستر ال النموذجي الخاص بالمعاملات

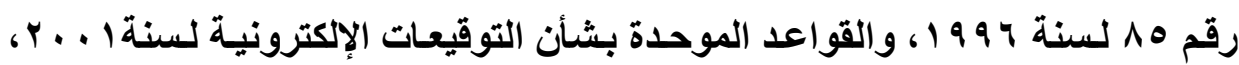

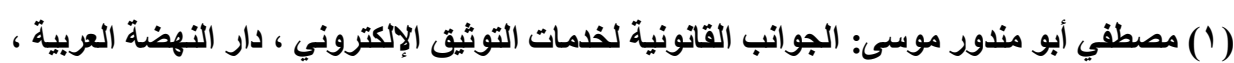

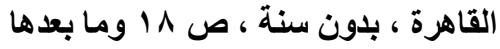


د/ أشرف محمد إسماعيل عدد خاص بالمؤتمر الدولى السنوى العشرون

ومن ثم تبعتهـا قواعد التوجيـه الأوروبي لسنة . . . ب، وعملت كافـة الدول العربيـة ومنها المشرع المصري على سن تثريعات وطنية ، تنظم المعاملات الإكترونية ضمن

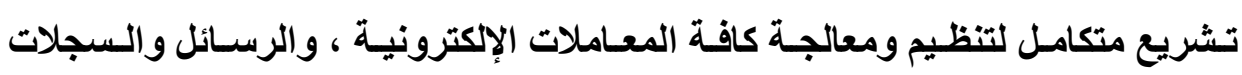
والسندات الإكترونيـة (')، وبحث مدى قوتها في الإثبات ومسئولية أطراف المعاملة والجهة المنظمة لإصدار تلك المحررات والوثائق.

\section{مشكلة الدراسة:}

مـع تعـاظم حجم وصور المعـاملات الإكترونيـة في ظل تطور التقتيـات وتنـامي استعمال الحاسوب والإنترنت ، وانتثار ثقافة المعلوماتية بين الجمهور ، كل ذلك تطلب ايجاد وسائل اتصال أكثر سرعة وايجابية بين الأفراد في شتى بقاع الأرض ، ممـا نتج عنه تطور أنماط التعاقدات ومن بينها عقود الزواج ، وذلك من النمط اليدوي المـادي إلحى النمط الإكترونـي أو اللامسادي ، حيث يعتبر هذا التطور مـن أبرز ســات الثورة المعلوماتيـة في مجـال المعـاملات الإلكترونيـة في فضاء العـالم الافتراضسي ، ممـا خلق تحديات قانونية كثيرة ، وللتفلب على مشكلات التلاعب والتحريف أو التغيير في عقود الزواج ، سواء من قبل الزوج أو الزوجة ، فقد تم إيجاد آلية قانونيـة لتأمين التعاملات وهي "التوثيق الإكتروني"، وهي عمليـات تقوم بها جهات متخصصة مهمتها تأمين سـلامة المعاملات والبيانـات التي تتم عبر وسيط إلكترونـي من حيث مضمونها ودقة نسبتها إلى مُصدرها ، وحفظها ، وإصدار شـهادات يمكن الاعتمـاد عليها ، وبـللك يتم التثبت من كافة البيانات الشخصية التي يالي بها كلاً الزوجين عند إبرام عقد الزواج 
سواء المتعلقة منها بالسن القانوني للزواج ، أو الحالة الاجتماعية للزوجين أو غيرهـا من البيانات الهامة الأخرى وربط ذلك بشبكة معلوماتية مُحكمة (')

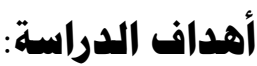

تهـدف هـذه الدراسـة في تسليط الـضوء على أهميـة توثيق عقدود الـزواج إلكترونياً، والذي يحقى عدة أهداف ، من أهمها تحديد هوية أطراف الزواج على وجه

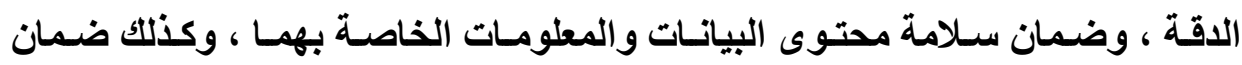
السرية الكاملة لتلك البياتـات ، والبعد عن أي تحريف أو تغيير أو تعديل في مضمون تلكك البيانات التي يُدلي بها كلاً الزوجين عند الإقدام على الزواج ، لمـا يحققه التوثيق الإكتروني من مزاياً عديدة سواء من حيث حفظ أو استرجاع أو نقل تلك المعلومـات والبيانات الشخصية ، بطريقة مؤمنة.

\section{منذهج الدراسة:}

اعتمـدت تلـك الدراسـة على المـنهج التحليلـي المقـارن لنصوص التشريعات الإكترونيـة المختلفـة ، وأبرزهـا التشريع المـصري الخـاص بالمعـاملات والتوقيعـات الإكترونيـة رقم (0 1 ) لسنة ؛ . . ب ، مـع التطرق لبحث ذلـك في القوانين الدوليـة

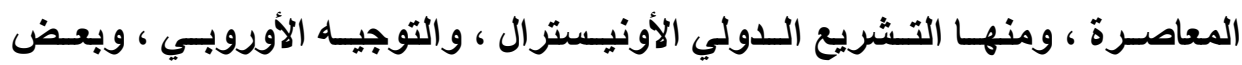

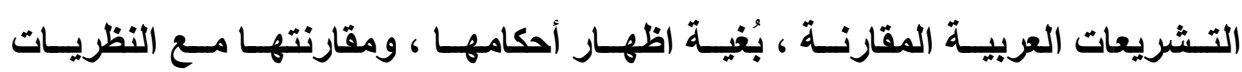
والاجتهادات الفقهية وشراح القانون.

(1) مصطفي أبو مندور موسى: الجوانب القانونية لخدمات التوثيق الإكتروني ، مرجع سابق. 
وتتنـاول هذه الدراسـة بيـان مفهوم التوثيق الإكترونـي ، والمقصود بشهادات

وجهات التوثيث الإكتروني وأثر ذلك شكلية عقود الزواج ، كما تتناول اظهار الضوابط القاتونية لجهة التوثيق الإكترونية من خلال تحديد الالتزامسات المترتبة على عاتقها ، وبيـان مسئوليتها المدنيـة في حالـة الإخلال بتلكك الالتزامـات ، وذلك مـن خلال تقسيم الاراسة إلى مطلبين أساسيين ، على النحو التالي: المطلب الأول: التوثيق الإكتروني وأثره على شكلية عقود الزواج. - الفرع الأول: المفهوم القانوني للتوثيق الإكتروني. - الفرع الثاني: أثر التوثيق الإكتروني على شكلية عقود الزواج.

المطلب الثاني: الضوابط القانونية لجهات التوثيق الإكترونية. - الفرع الأول: التزامات جهة التوثيق الإلكتروني. - الفرع الثاني: المسئولية المدنية لجهة التوثيق الإكترونية. الخاتمة: وتشمل (النتائج والتوصيات). 


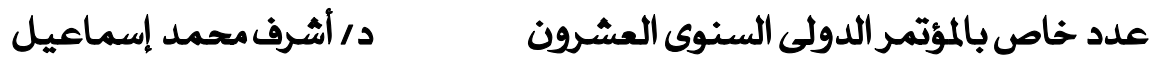

\section{المطلب الأول}

\section{التوثيق الإلكتروذي وأثره على شكلية عقود الزواج}

لقد صاحب التقدم التكنولوجي والتقني ظهور عدة مسميات ووسـائط تكنولوجية لإيجاد بيئة قانونية أمنة تعني بضمان وسلامة وتأمين التعامل عبر الإنترنت ، ومن هذه وهي

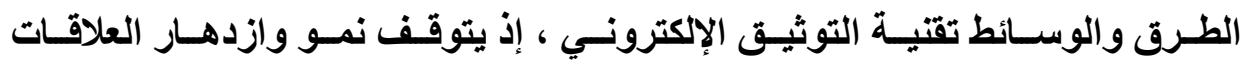

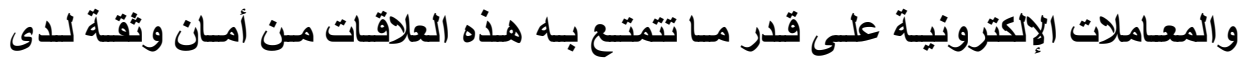
مستخدمي وسائل التقنية الحديثة ، وقد ألقى ذلك بظلاله على كافة العقود القانونيـة بمـا

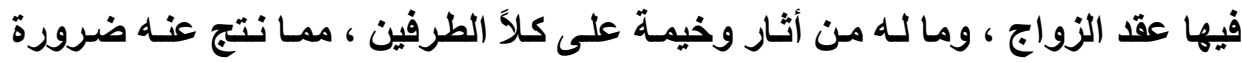
ملحة لإيجاد تقتية التوثيق الإكتروني والطرف الثالث المحايد الذي يكون دورة متمثلاً في التأكد مـن صـحة الإرادة وإسـنادها وجديتها ومقدرتها على التنفيذ وبعدها عن الإن التلاعب أو التغيير، وعلى هذا سوف نقسم المطلب إلى فرعين رئيسيين ، وهما: الفرع الأول: المفهوم القانوني والفقهي للتوثيق الإكتروني. الفرع الثاني: أثر التوثيق الإكتروني على شكلية عقود الزواج. الفرع الأول: الافهوم القانوني والفقهي للتوثيق الإلكتزوني مفهوم التوثيق هـو التصديق والتأكيد (')، ويتضح ذلك جليـاً في التصرفات القانونية في شكلها التقليدي ، أي المستندات الورقية ، عندما يضع موظف عام مختص هول تأكيده وتصديقه على صحة ما ورد في المستند المقدم للتصديق وصحة نسبته إلى من

(1) Thierry Piette -Coudol, $<$ Certification electronique: pratique et modelisation>, http:llwww.e-betobe.coml texteece, htm. 
وقع عليه ، مراعياً في ذلك الأوضاع التي يتطلبها القّانون لإبرامهه ، وهذا التوثيق هو الذي يضفي عليه الصفة الرسمية ، ومن ثم يكسبه الحجية القانونية. و التوثيق الإكترونسي وسيلة فنية أمنـة للتحقق من صحة التوقيع أو المحرر برمته ، حيث يتم نسبته إلى شخص معين عبر جهة موثوق ومصدق بها ، أو طرف محايد يسمى بجهات التوثيق ، وعلى ذلك يقتضي الأمر للتعرف على ماهية التوثيق الإلكتروني التطرق لعدة أمور منها:

أولاً: مفهوم التوثيق الإلكتروني من الناحية القانونيـة: على الرغم من أن

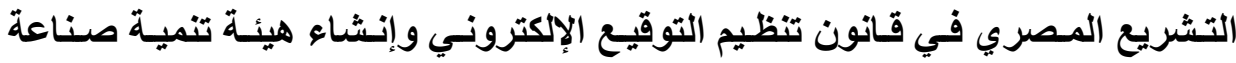

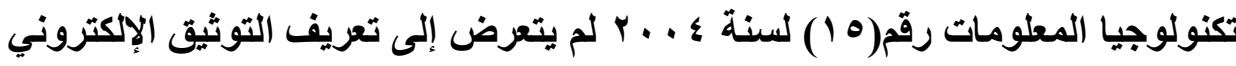
أو إجراءاته ، إلا أنه بالرجوع إلى اللانحة التتفيذية الخاصة بالقانون يمكن استخلاص مفهوم التوثيق من خلال المصطلحات التي وردت في هذه اللانحة ، حيث ورد تعريف لجهات التوثيق الإلكتروني في البند 1 من المادة 1 من اللانحة بالقول بأن هذه الجهات عبارة عن: جهات مرخص لها إصدار شهادة التوثيق الإكترونسي ، وتقديم خدمات تتعلق بالتوقيع الإكتروني ، كما ورد في البند V من ذات أن شهادة التوثيق الإكتروني

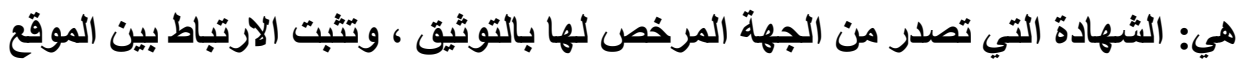

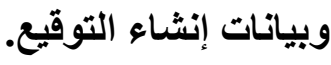
وحيث أن التوثيق عبارة عن وسيلة فنية أمنة تستخلم للتأكد من صحة التوقيع

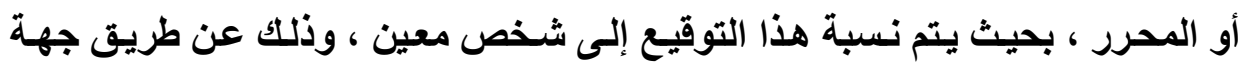

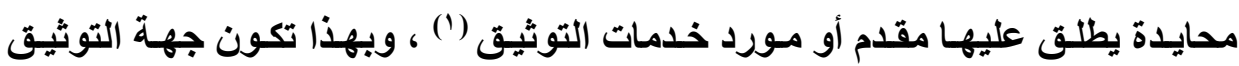

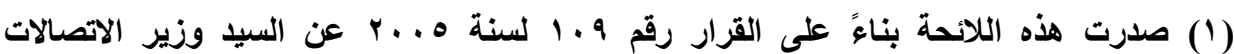

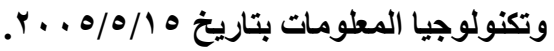


د/ أشرف محمد إسماعيل عدد خاص بالمؤتمر الدولى السنوى العشرون

الإكتروني وعن طريق إصدارها لثهادة التوثيق قد قامت بعملية التوثيق والتأكد من صحة التوقيع وربطه بالبيانات الواردة بالمحرر.

ثانيـاً: مفهـوم التوثيـق الإكترونــي مـن الناحيـة الفقهيـة: حساول بعضض

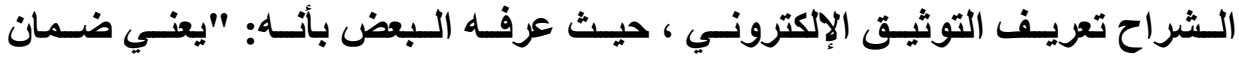
سـلامة وتأمين التعامل عبر الإنترنت ، سواء من حيث أطرافه ومضمونه ، ومحله ،

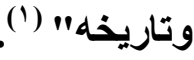

وكذلك عرف بعض الققه التوثيق الإلكترونسي بأنها: عبارة عن إجراعات معينة الهذف منها تمكين التوقيع الإكتروني من تصديق السجل الإكتروني ، والتأكد من عدم تعرض القيد الإكتروني لأي تعديل أو تلاعب من تاريخ إتمـام إجراعات التوثيق ، وهذا

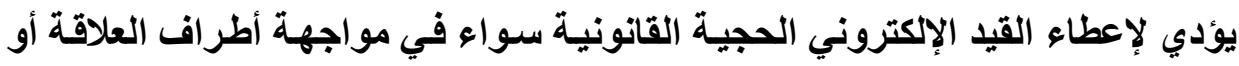
الغير ، كما يؤدي إلى الحفاظ على حقوق المتعاملين من أي اعتداء قد يقع عليهم ، لا

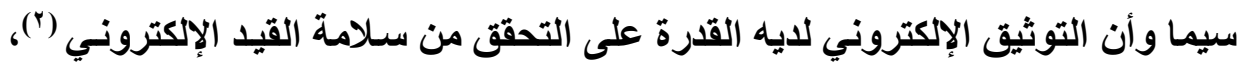
إضافة إلى قدرته على الحفاظ على حقوق المتعاملين والأطراف من أي غش أو اعتداء قـ يمارس عليهم من قبل الغير (") لذا يمكن تعريـف التوثيتق الإكترونـي بأنـه: الوسـائل التـي تقوم بهـا الجهات

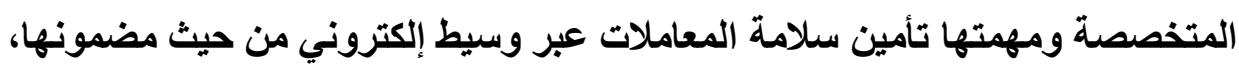

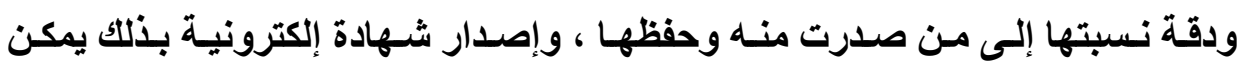

(1) مصطفي أبو مندور موسى: الجوانب القانونية لخدمات التوثيق الإكتروني ، مرجع سابق ، ص

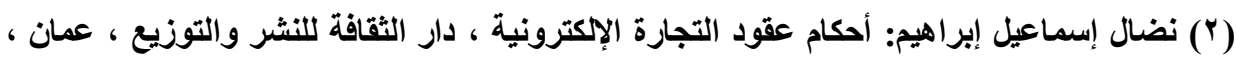

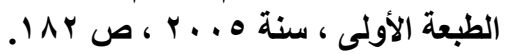

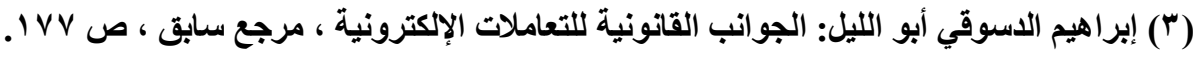


الاعتمـاد عليهـا في إنجاز هذه النوعيـة من المعـاملات ، إذ أنسه إجراء يتم عن طريق طرف ثالـث محايـــ ومعتمــ ، عن طريـق اتبـاع بعض الإجراءات الفتيـة والـضوابط القانونيـة بهدف تثبيت مضمون المحرر الإكترونـي ، والبعد عن التلاعب والتغيير ، ودقة ما يحمله من توقيعات ، وصحة نسبته إلى من صدرت عنه ('). ثالثًاً: مفهوم جهات التوثيق الإكترونسي: لقد اهتمت القوانين والتشريعات الدولية والوطنيـة الخاصـة بالتعامل الإكترونـي بوضع القواعد الخاصـة بتظيم جهات التوثيتق الإكترونـي ، مـن حيث إنشائها وكيفيـة ممارستهـا لنشاطها والرقابـة عليها ومسئوليتها () و وتختلف تسميات جهات التوثيق في التشريعات العربية والدوليـة ، حيث يسسمى بمقدم خدمات التصديق في التشريع العــاني ، وتسسمى أيضا بجهـات التصديق الإكترونسي في التشريع المـصري ، وتسمى بمـزودي خدمات المـصادقة الإكترونية في التشريع التونسي أو مراقبي خدمات التصديق حسب القانون الإماراتي ، ورغم اختلاف مسميات التوثيق الإكترونـي في التشريعات والقوانين المختلفة لكنها تثقق في المضمون وطريقة عملها ، وهذه التسميات معبرة عن حقيقة الدور المنوط بهذا الثخص أو الجهة المعتمدة المحايدة ، والأي يتمثل في تأكيد وتصديق المعاملة وبث الثقة في نفوس المتعـلين عبر الإنترنت من خلال اتبـاع مجموعة من الوسـائل

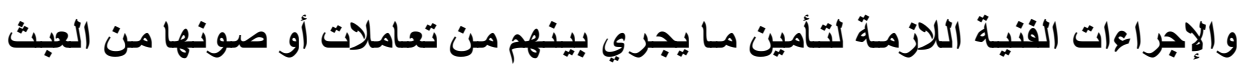

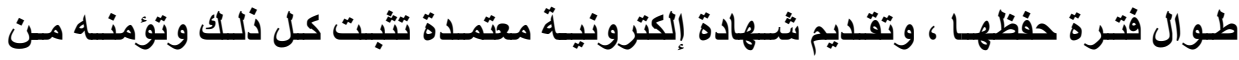
العبث (r) (")

$$
\text { (1) (1) مصطفى أبو مندور موسى: مرجع سابق ، ص بr. }
$$

(2) A Michal Froom Kin, The Essential Role of Third Trusted Parties in Electronic, Commerce, Buffialo Law Journal, 1996 At 2-11.

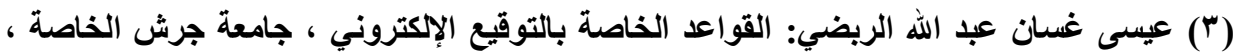

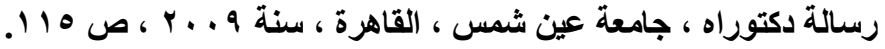




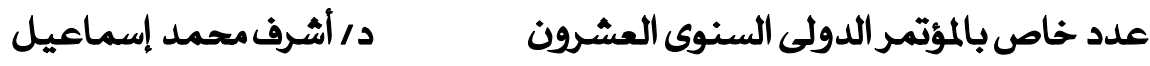

وقد استخلم التشريع المصري مصطلح التصديق الإكترونسي وعرفها بأنها:

" هي الجهات المرخص لها بإصدار شهادة التصديق الإكترونـي وتقديم خدمات تتعلق لـ بالتوقيع الإلكتروني"

وغني عن البيان أن جهات التوثيق الإكتروني قاصرة على الأشخاص المعنوية

فقط ، ممـا يجعل مـن هذا التعريف تعريفـاً عصرياً يتماشسى مـع الواقع لصعوبة قيـام الشخص الطبيعي منفرداً بأعمـال التوثيث الإكترونـي نظراً للتكلفـة العاليـة والتقتيـة

والأجهزة التي تحتاجها عملية التوثيق (')

كما أشار قانون الأونيسترال النموذجي الدولي مصطلح "مقدم خدمة التصديق"

في المادة(ץ) فقرة(ه)، وعرفه بأنه "شخص يصدر شهادات ، ويجوز أن يقدم خدمات أخرى ذات صلة بالتوقيعات الإكترونية"، وهذا التعريف قد أشـار إلى أن مقدم الخدمـة يمكن أن يقدم خدمات أخرى لها علاقة بتقتيـة التوقيع الإكترونسي ، حيث لـم يفرق القـانون بين الأحوال التي تمـارس فيها جهة التوثيق هذا النشاط باعتبـاره النشاط الرئيسي أو بوصفه العمل الفرعي ، ويلاحظ أيضا ذكر لفظ شخص فقط وهو لفظ يشمل بلا ريب الشخص الطبيعي والمعنوي على السواء ().

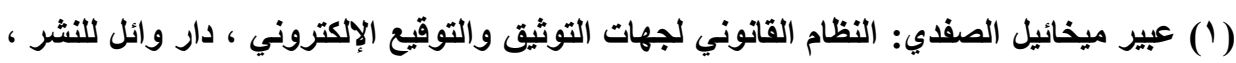

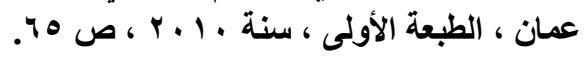

(2) Article 2:"(e) Certification service provider means a person that issue certificates and may provid other services related to electronic signatures".

وانظر في ذلك أيضا: علاء حسين مطلق التميمي: الاليل الإكتروني في الإثبات المدني ، دار النهضة

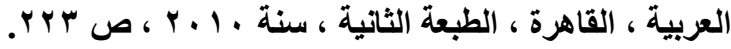

rv. مجلة البحوث القانونيت والإقتصاديت 
ومن الناحية الفقهية فقد عُرفت جهات التوثيق الإلكترونسي من جانب البعض أنس على أنها: "شـخص طبيعي أو معنوي عـام أو خـاص مرخص أو متفق عليـه يخضع لإشراف الدولـة ورقابتها ليقوم بدور الوسيط الإكتروني عن طريق إصدار شـهادات توثيتق إلكترونيـة تحدد هويـة الشخص المرسـل بالإضـافة إلى خدمات أخرى تتعلق بالتوقيع الإكتروني (')" الكئي

ومما تقدم نلاحظ أن جهات التوثيق الإكترونسي هي جهات ذات أهمية كبيرة ، حيث تمثل الدور الرئيسي والهام في منظومـة التعـاملات الإلكترونية ، ولهيا العديد من الوظائف ، ومنها على سبيل المثال لا الحصر ، فهي تصدر شهادات التوثيق طوال المدة التي يحددها القانون ، كما تقوم بوظيفة عمل نظام لتحديد تاريخ ووقت إصدار شههادات التوثيث ، وإنشاء نظام لإيقاف شهادة التوثيق وتعليقها وإلغائها ()، وإنشاء نظام محكم لحفظ بيانات التوقيع الإكتروني ومنعه من التلاعب أو العبث بالمحررات ("). ويمكن إيجاز أهم وظائف جهات التوثيق الإكتروني في الآتي: - إصـــار شـهادات التوثيـق الإلكترونيـة لمعرفـة هويـة المتعـاملين وأهليـتهم القاتونيـة وصـلاحيتهم للتعاقد ، والتحقق مـن مضمون هذا التعامـل وسـلامته

\section{وجديته بطريقة أمنة ومشفرة (؛)}

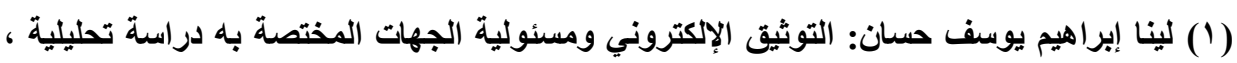

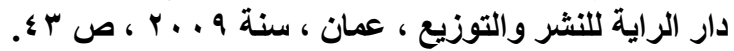

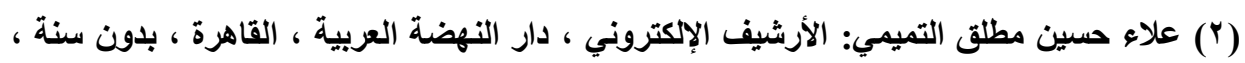

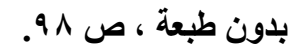

(ّ) محمد حسين منصور: الإثبات التقليدي والإلكتروني ، دار الجامعة الجديدة ، الإسكندرية ، سنة

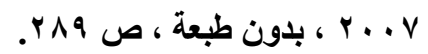

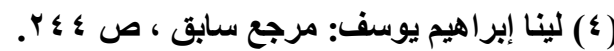


- - التحقق مـن صـحة البيانـات المقدمة عن طريق مـا يعرف بمعالجـة البيانـات الإكترونية (') التي تحظر على جهات التوثيق حذف أو تعديل أو إضافة أياً من

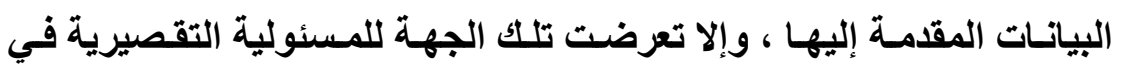
مواجهـة أي شـضص يعول على هذه البيانـات الخاطئسة والـواردة في شـهادة التوثيق ، إذ أنها مقيدة بالمبـادئ والسياسـات المعلنة في مواثيقها ونشر اتها

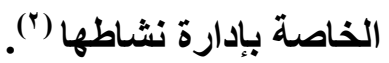
- - إصدار توقيعات رقمية عن طريق المفـتيح الإلكترونيـة سواء المفتـاح الخـاص الذي يتم به تشفير الرسائل والتوقيعات الإكترونية ، أو المفتاح العام الذي يتم بمقتضاه فلك التشفير. - عمل أرشيف للمعلومـات المرتبطة بالشهادات التي يتم إصدارها عن طريق سجلات خاصة بالثهادات الصالحة للاستعمال والملفـاة والموقوف العمل بها (")، وتاريخ الإلغاء أو الوقف ، وإنشاء قاعدة بيانات ومعلومات.

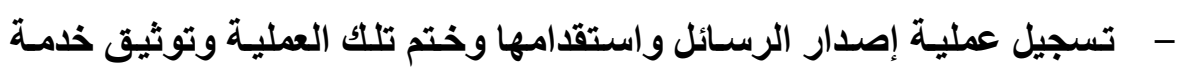
التاريخ.

\section{الفرع الثاني: أثر التوثيق الإلكتروني على شكاية عقود الزواج}

مسن القضايا الهامـة في حيـاة الإسـسان واسـتقامة المجتمعـات ، تلـك القضايا المتعلقة بـالزواج ، إذ اعتـى الفقه والقوانين الوضعية ومـن بينها القانون المصري بالزواج وقوانين الأسرة بوجه عام لكي تتماشى مـع بـاقي التشريعات الدولية والعربيـة

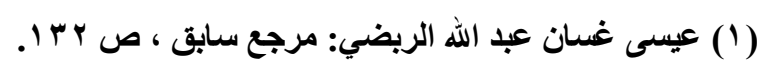

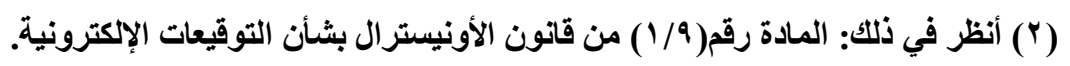

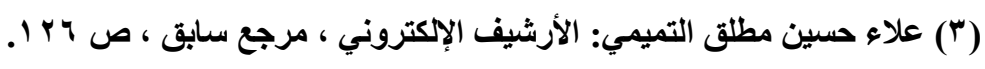


الحديثة ، فبالزواج تتكون العائلـة والأسرة التي تعتبر أهم تركيبة اجتماعية ، وذلك لطابعها المميز ودورها الأساسي والفعال في تحريك المجتمع وتغييره ، ويعتبر الزواج

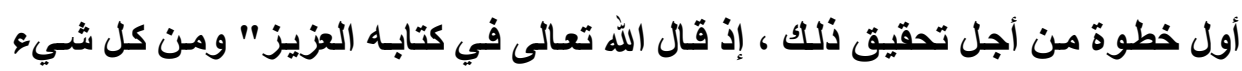
خلقنا زوجين لعلكم تذكرون" (')، ولقد كرم الله عز وجل الإنسان عن سـائر المخلوقـات ولم يتركه لما تميل له غرائزه ونزواتـه الشخصية ، فشرع لـه الزواج من أجل تكوين أسرة تستتد في قيامها على المودة والرحمة ، وتحقيق التكاقل والترابط بين الزوجين ،

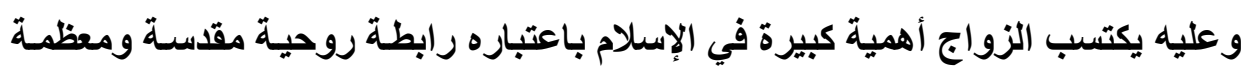
بنظام شرعي وقانوني لتكوين الأسرة.

ولقد حساول الفقهاء تنظيم عقد الـزواج مسن حيث مفهومسه وتحديـد شـروطه وأركانه بمختلف مذاهبهم ، واختلفواً في العديد من الأمور وكل مذهب استتد في خلافه إلسى مبـادئ وآيـات قر آنيـة أو أحاديث نبويـة ، وقسم كل منهم شـروطاً لـصحة الزواج ونفـاذه ببين الطرفين وفي مواجهة الغير ، بعد الاتفـاق على الأركـان العامـة لانعقـاده باعتبارها من الأمور الثابتة التي لا خلاف عليها. وإذا كان التوجيه في القرآن الكريم على توثيق المداينات بين النـاس بالكتابـة ، وأن يكتب بينهم كاتب بالعدل في قوله تعالى:" يا أيها الذين أمنوا إذا تداينتم بدين إلى لى أجل مسمى فـاكتبوه وليكتب بينكم كاتب بالعدل" (؟)، فـإن توثيق عقد الزواج بحجـة رسمية يكون من باب أولى ، إذ أوجب الظاهرية وغيرهم كتابة عقود الدين ، وبالتالي فكتابـة وتوثيق عقود النكاح أو توثيق وكتابـة الأمسور الأخرى من طلاق أو رجعة أو أو وقف أو وصية أو ايصاء أو صداق أو نفقة أو غير ذلتك يكون أوجب ، وذلك لأن عقد 
الزواج عقد عظيم الأثثر ، ومحلـه شـديد الحرمـة ، وتتعلق بـه حُرمسات ، وتنشأ عنـه

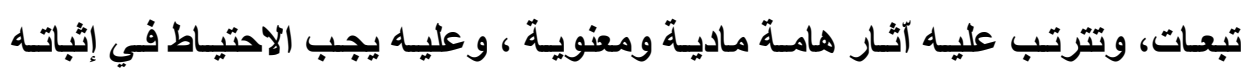

وتسجيله ، ولا بل من قواعد تحمل الناس على الدقة والنظام في هذا الأمر الخطير ('). ويقصد بتوثيق الزواج تحريره وصياغته مستوفياً لشروطه الشرعية أو تثبيته وتسجيله في محرر رسمي مكتوب من قبل موظف خـاص تـابع لجهة إداريـة موثوق فيها، على أن يكون الغرض من إدراجه داخل نصوص قوانين الأحوال الشخصية ليس لانعقاد الزواج أو صحته ونفاذه فقط ، بل لافع بلاء عم وجوده ، وقيام الحاجة للحيلولة دون أثاره بحكم الواقع الذي أطل بأثاره السيئة على المجتمع ، ويتمثل ذلك في تقييد زواج الصغار ، والفحص الطبي ويظل البـاب مفتوحاً لغيرهـا طالمـا كـان الأمر حمايـة الحقوق أخذاً وعطاءاً في الأسرة ، فشرط توثيق الزواج إقتضاه فساد النفوس ، واتساع الأمم ()، وما نتج عن ذلك من ادعاء الزواج أو جدده وإنكاره زوراً أو كذباً ، وتلاعب التـاس بهذا العقد الخطير لهدف مسادي كسبي أو كيدي نفسي ، وقد نـصت المـذكرة

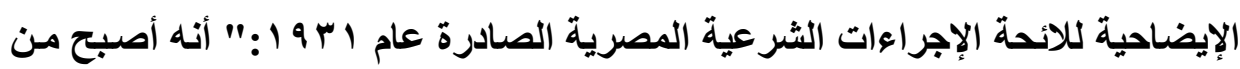
المألوف أن تدعي امر أة صسلوكه الزواج من رجل مليء بـالاحترام والثروة طمعاً في ثروته وجاهه ، ولا تعدم أن تؤيد دعواها بعديد من الشهود ، كما أصبح من المألوف أن يدعي رجل من حثالة المجتمع الزواج بامرأة على جانب كبير من الثراء ، أو على قدر من الجمال لا يعدم الاعتماد على الشهود الزور والبيانات الملققة" (").

(1) محمد فوزي فيض الله: الزواج وموجباته في الشريعة الإسلامية ، مكتبة المنار الإسلامية ، بدون سنة نشر ، الكويت.

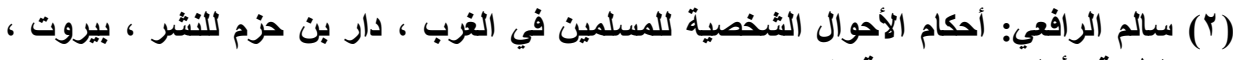
الطبعة الأولى ، بدون سنة نشر.

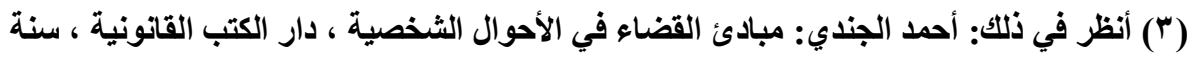

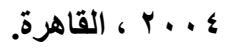


وهذا ما قررته أيضا غالبية التشريعات العربية ، ومنها التشريع الكويتي ، فقد

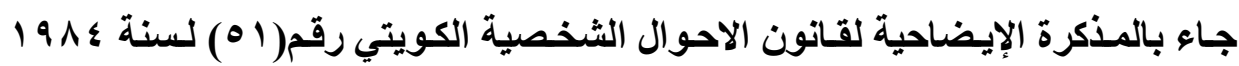

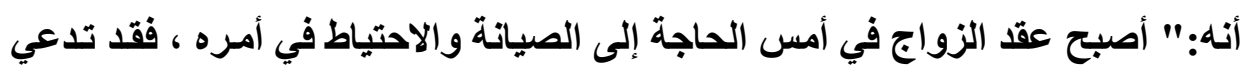

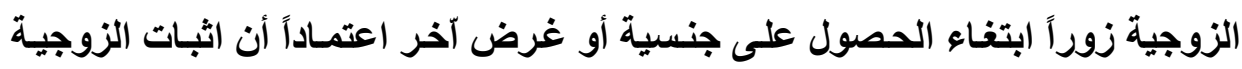

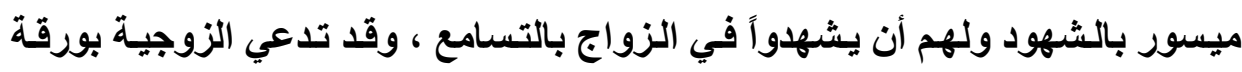

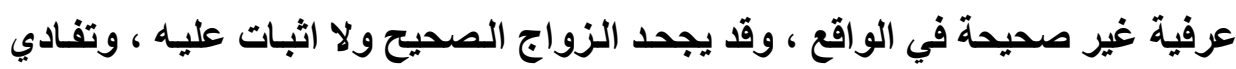

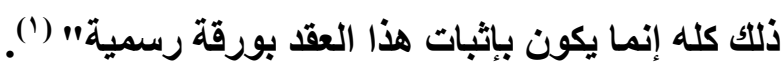

وقد استقر الفقه والقضاء على أنه يشترط لسماع دعوى الزوجية وجوب ثبوتها

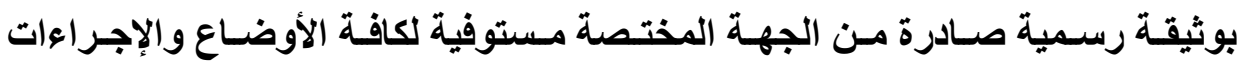

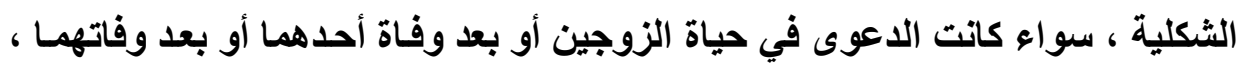

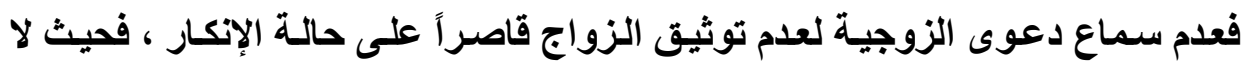

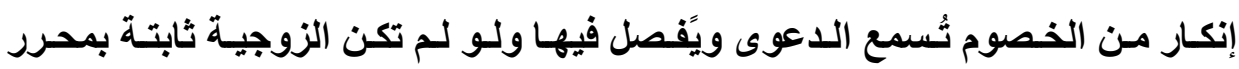

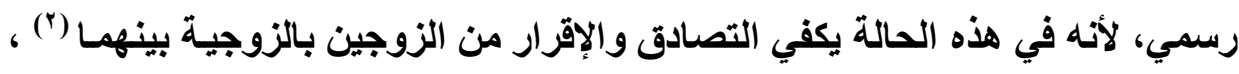

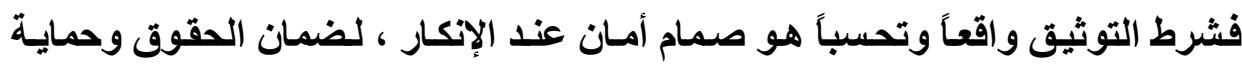

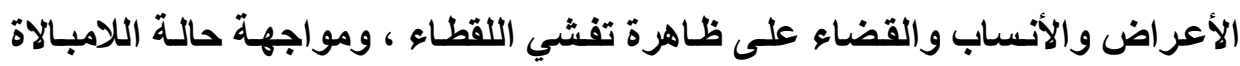

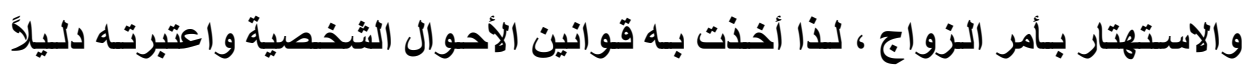

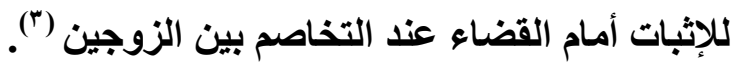

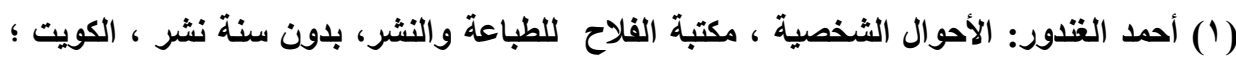

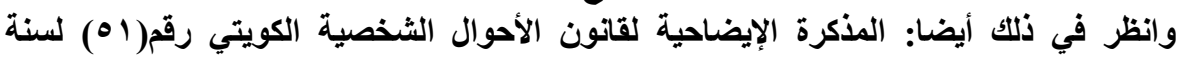

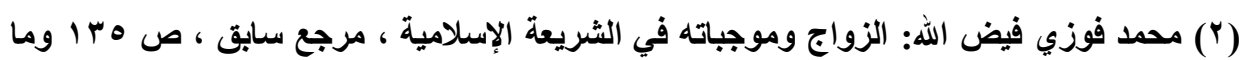

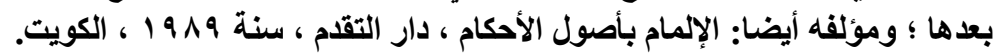

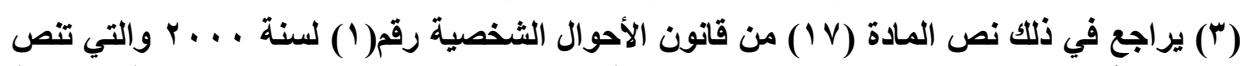

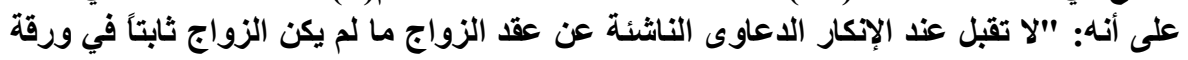


وينبغي القول بأن الزواج غير الموثق بالوثائق الرسمية ، من الأمور التي لا

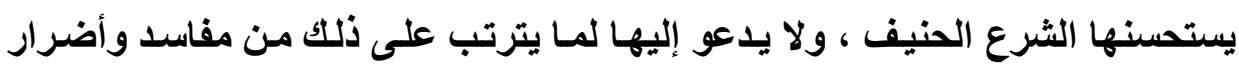

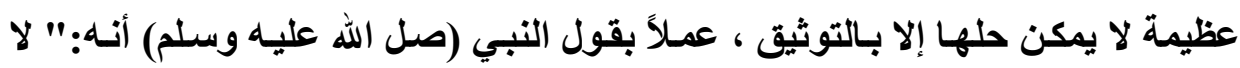

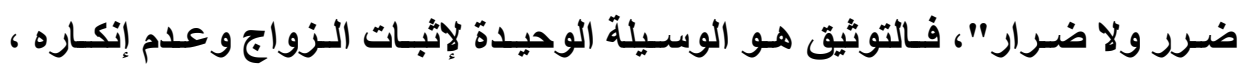

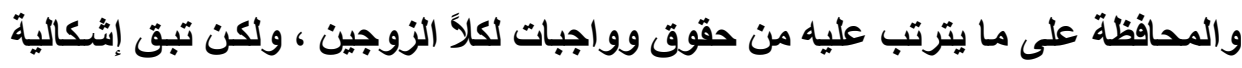

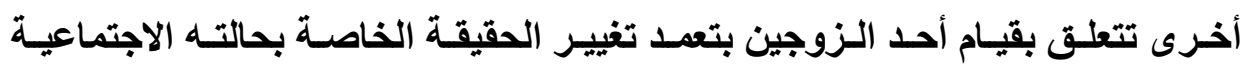

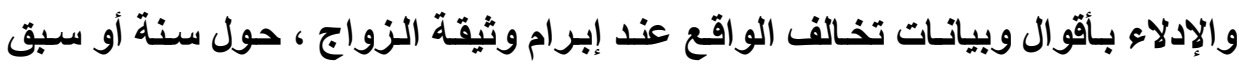

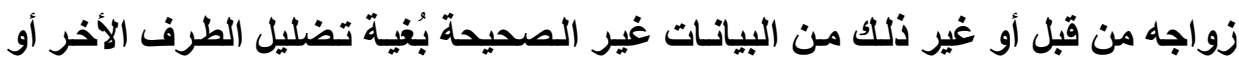

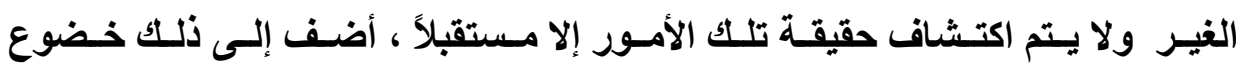

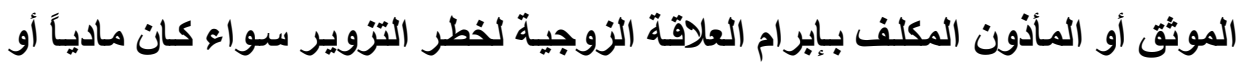
معنوياً.

من أجل ذلك ظهرت الحاجة ملحة لإصدار وثائق زواج إلكترونية حديثة من قبل

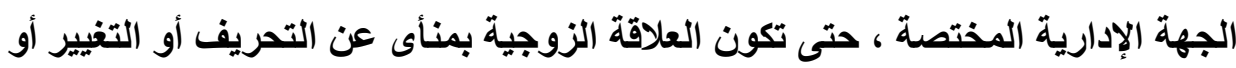

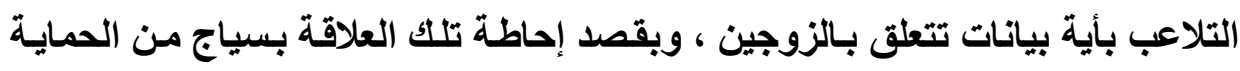

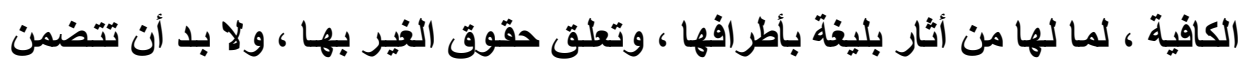

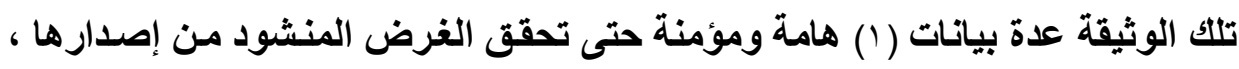

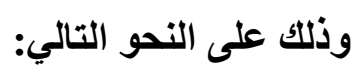
أولاً: البيانات الواجب توافرها في الوثيقة الإكترونية:

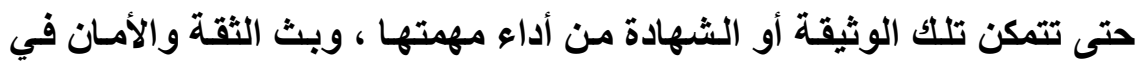
نفوس المتعاملين ، فلا بل من أن تتضمن المنطلبات الأتية:

( (1) عيسى غسان عبد الله الريضي: القواعد الخاصة بالتوقيع الإكتروني ، مرجع سابق ، ص I I I. 
د أشرفمحمد إسماعيل عدد خاص بالمؤتمر الدولى السنوى العشرون

• أن ثُمنح من قبل طرف ثُالث موثوق أو من قبل مؤدي الخدمات الإكترونية ، واسم الموقع الإكتروني المصدر لتئك الوثيقة. • إشارة أو ما يفيد أنه قد تم منح تلك الوثيقة على أسساس أنها وثيقة إلكترونية

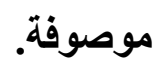

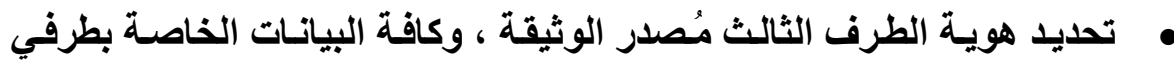

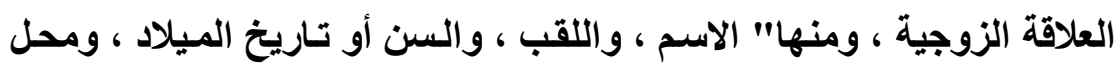

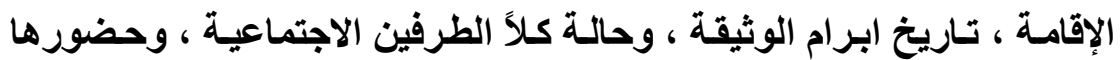

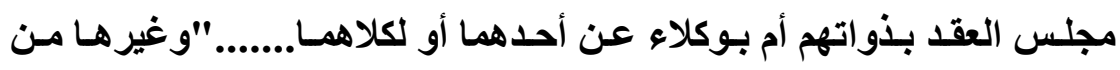

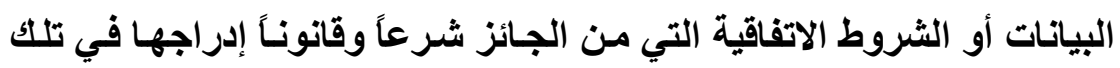

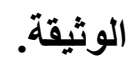

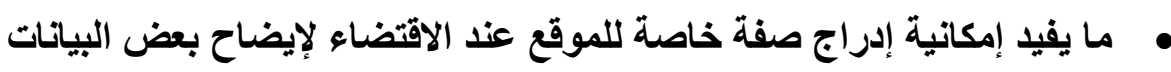
أو استخراج نسخ من الوثيقة الإكترونية. • رمز تعريف للوثيقة الإكترونية. • • ما يفيد صحة ونسبة التوقيعات لكلاً الطرفين.

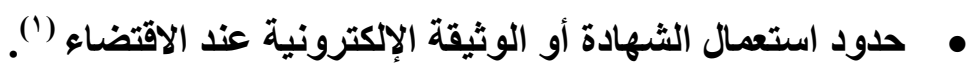
• ربط تلك الوثيقة بشبكة معلوماتية مُحكمة درعاً لتلاعب أحد الطرفين أو قيامسه بتغيير بعض بياناته الحقيقية. 
ثانياً: الشروط القانونية للزواج:

ويقصد بها تلك الثروط التي وضعها المشرع للتأكد من قدرة كلاً الزوجين على تحمل مسئولية الزواج ، ومعرفة كل طرف بما يترتب على الزواج من التزامات وحقوق

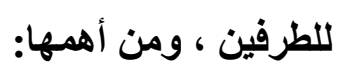

• بلوغ السن القانونية لتوثيق الزواج والأي نص عليه القانون رقم

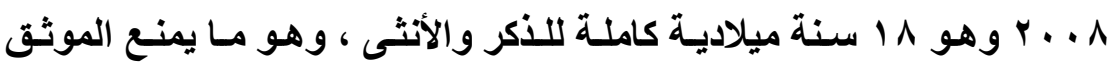
المختص عن توثيق عقد الزواج إن لم يبلغ العاقدين هذا السن.

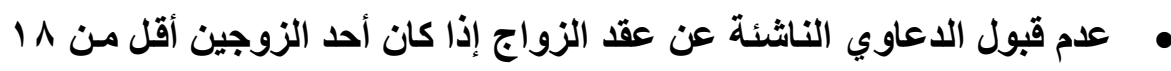
سنة ميلادية وقت رفع الدعوى.

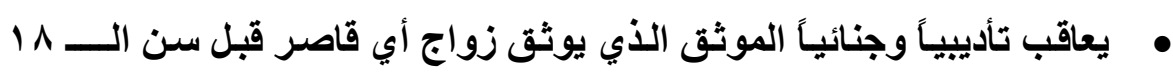
عاماً أو من يثبت في وثيقة الزواج سناً غير السن الحقيقية لأحد الزوجين.

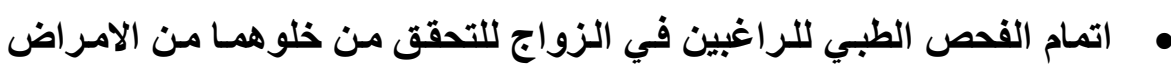
التي تؤثر على حيـاة أو صحة كل منهمـا أو على صحة نسلهما ، وإعلامهمـا

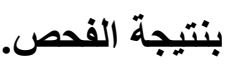

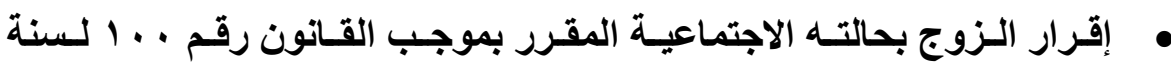
ه^a 19 الذي أضاف نص الفقرة الأولى من المادة 11 مكرراً للمرسوم بقانون رقم ه Y لسنة 9 و 9 و ، والتي تقضي: "على الزوج أن يقرر في وثيقة الزواج

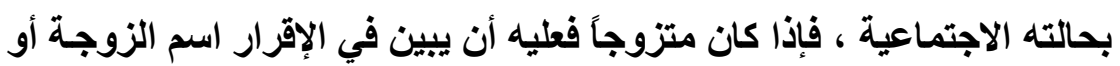
الزوجـات اللاتـي فـي عصمته ومحسال إقـامتهن ، وعلـى الموثـث إخطـارهن بالزواج الجديد بكتاب مسجل بعلم الوصول". 
ويعاقب الزوج الذي يدلي بييانات غير صحيحة عن حالته الاجتماعية أو محال

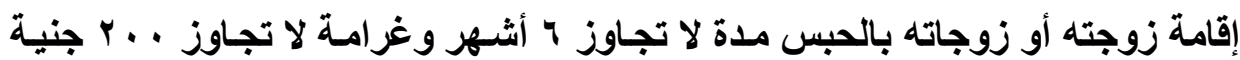

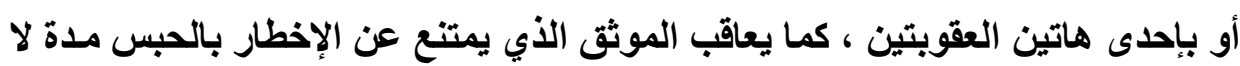

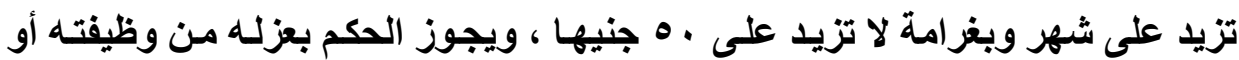
وقفه عن عمله لمدة لا تجاوز سنة.

كمسا تضمنت المسادة بr مسن لائحسة المسأذونين المسصرية على بعض الشروط الخاصة الجائز إدراجها في عقود الزواج ، فقضت: "على وجوب أن يبصر المسأذون الزوجين بما يجوز لهما الاتفاق عليه من شروط خاصة ، ومنها":

- - من يكون له حق الاتتفاع وحده بمنزل الزوجية في حالة الطلاق أو الوفاة. - عدم اقتران الزوج بأخرى إلا بإذن كتابي من الزوجة.

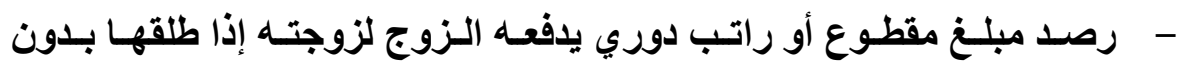
رضاها ، وتفويض الزوجة في تطليق نفسها. ثالثاً: مميزات التوثيق الإكتروني لعقود الزواج: يكتسب المحرر الإكترونسي قوتـه وحجيتهـ في الإثبـات مسن خـلال مـا يسمى "بعمليات التوثيق الإكتروني"، تلكك العمليات التي تقوم بها في الوقت الراهن جهـات متخصـصة مهمتهـا تـأمين سـلامة المعـاملات التي تـتم عبـر وسـيط إلكتروني من حيث مضمونها ودقة نسبتها إلى من صدرت منسه ، وحفظها ،

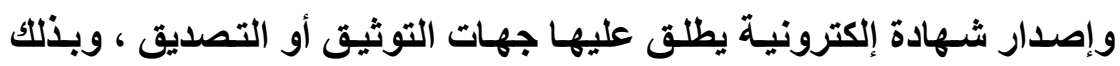
يمكن الاعتماد عليها في إنجاز هذه النوعيـة من المعـاملات من خلال وسيلة أساسية هي "آلّة التثفير" سواء كان تثفير متماثل أو غير متماثل ، ولا شك أن توثيق عقود الزواج إلكترونياً يحقق بعض المزايا ، وأهمها: 
(1) منع التلاعب أو التحريف أو التغيير في البيانات الخاصـة بـالزوجين عند إبرام الزواج ، لربط ذلك بشبكة وبرنامج آلـي مؤمن (') يوضـح السن القـانوني لكلاً الزوجين ، والحالة الاجتماعية لهما وغيرها من البيانات الهامة. لزئ.

(Y) تخزين صور الوثائق إلكترونياً بوصفها محرراً صـالحاً ومعداً للإثبات ، ويتم الاحتفاظ به عن طريق إدخال المعلومات وبنود الاتفاق بين الطرفين وتخزينها

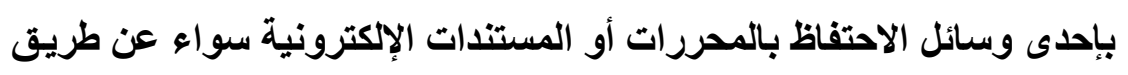
الشريط المغناطيسي ، أو شبكة الإنترنت وإدخال رموز التعريفات على الموقع ، أو عن طريق الأقراص المرنـة ، الأمر الذي يجعل مسألة استرجاع الوثيقة واستخراج نستخ منها مطابقة للأصل في غاية السهولة. (r) عدم مراجعة المحكمة لتوثيق عقد النكاح. (ع) ) إعادة إصدار وثيقة الطلاق للزوجة. (•) تسهيل نقل واسترجاع المعاملـة وكافة البيانـات إلكترونياً ، وذلكك بعد إدخالها

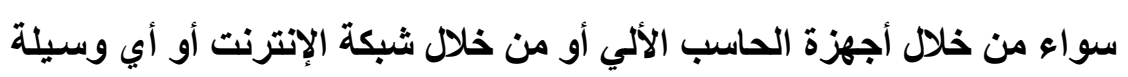
إلكترونية مُشابهة ، ويتم الاسترجاع والنقل من خلال أي جهاز إلكتروني يمكن

$$
\text { ربطه على الثبكة. }
$$

(ד) وصول المعاملة إلى القاضي إلكترونياً بشكل مباشر.

حماية الزوجة من تهاون الزوج في حالة تقاعسه عن توثيق عقد النكاح. (V) (^) إعفاء المأذون الثرعي عن مسك دفاتر الضبط وتلاشي كافة الأخطاء الماديـة التـي من الجـائز حدوثها أثـــاء ابرام العقد ، بالإضـافة إلى تـوفير المعلومـات وتسهيل الإجراءات. - مئ. (1) علاء حسين مطلق: الجهة المختصة بإصدار شهادات التوثيق الإكتروني ، مرجع سابق ، ص به 
د/ أشرف محمد إسماعيل

عدد خاص بالمؤتمر الدولى السنوى العشرون

(9) إعادة إصدار عقد الزواج "بدل فاقد" وإعفاء الأزواج من الأهاب للمحاكم من

أجل تصديق وثائق النكاح.

الإطبا الثاني

\section{الضوابط القانونية لجهات التوثيق الإلكترونية}

إن جهات التوثيق الإكترونسي وبوصفها طرف ثالث محايد موثوق بها ، يقوم بدور الوسيط الإكتروني بين طرفي العلاقة العقدية ومنها عقود الزواج ، ومنوط بها إصدار شهادات توثيق إلكترونية تؤكد صحة البيانات والمعلومـات الواردة إليها ، ومن هنا كان لا بـ أن تخضع تلك الجهة لإشراف ورقابـة الدولـة خاضعة في إدارتها لعدة ضوابط قانونية تحدد التزاماتها لتحقيق الهدف المنشود من ورائها ، وإلا كانت مسئولة قبل الغير عن أية اضرار قد تتسبب في تحقيقها ، ومن أجل هذا سوف نقسم الدراسـة في هذا المطلب إلى فرعين رئيسيين وهما: الفرع الأول: التزامات جهة التوثيق الإكتروني. الفرع الثاني: المسئولية المدنية لجهة التوثيق الإكترونية. الفرع الأول: التراهات جهة التوثيق الإلكتزوني

تعددت التشريعات التـي نظمـت عمـل جهـات التوثيـق الإلكترونسي والشهادات الصادرة عنها ، وعلى الرغم من تعدد تلك التشريعات ، إلا أنها اتفقت جميعُها على التى التزامات عامة مشتركة ومتفق عليها بين مختلف التشريعات ، وهي: أولاً: الالتزام بـالتحقق مسن صـة البيانـات المُقدمسة: إن الهـدف الرئيسي والغاية المرجوة من إنشاء جهات التوثيق الإكتروني ، هو التحقق من صحة البيانـات

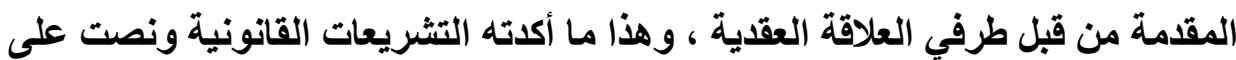


وجوبـه ، إذ تلتزم تلكـ الجهات مـن التحقق مـن هويـة الموقع وأهليـة وصـحة توقيع الطرفين ، وصفاتهم ، فقد نصت المـادة (r / /ه) من اللائحة التنفيذية لقانون التوقيع الإلكترونـي المصري بأنسه: " يجب أن يتوافر للدى جهات التوثيتق الإكترونـي نظامـاً للتحقق من الأشخاص المُصدر لهم شهادات التوثيق (') والتحقق من صفاتهم....إلخ". كمـانــص المششرع الـدولي علـى هـا الالتـزام في قـانون الأونيسترال بشأن التوقيعـات الإكترونيـة في المسادة (9/9): "يتعين على مقدم خدمات التوثيق أن يولي قدراً معقولًا من العناية لضمان دقة واكتمال كل ما يقدمه من تأكيدات جوهرية ذات صلة بالثهادة"، ويتطلب هذا الالتزام بوجه عام دقة وعناية خاصة ويحتاج إلى كادر وظيفي

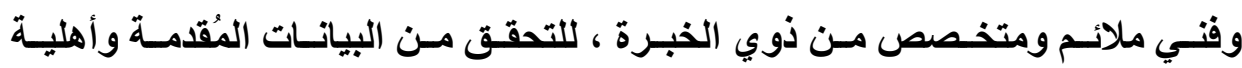

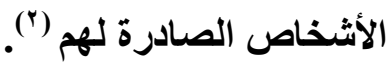

ويُعد هذا الالتزام أسـاس المعاملـة الإكترونية ومصدر الثقـة في هذا التعامـل

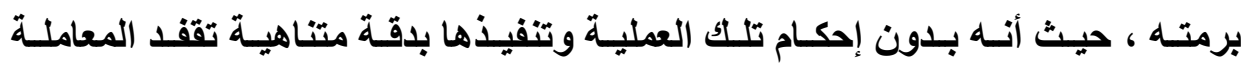
الإكترونية كل قيمة لها من الناحية القانونيـة ، ونظراً للتلك ومـا يترتب عليهه من أثـار سلبية في حالة الإخلال به ، فإن جهة التوثيق الإكترونسي تكون ملزمسة بالتعويض في حالة تضمين الشهادة بيانات غير صحيحة بشرط ألا يكون هناك تزوير في البيانـات من قبل صاحبها ، فهنا تكون المسئولية برمتها في حق المزور ولا تتعقد مسئولية الجهة ،

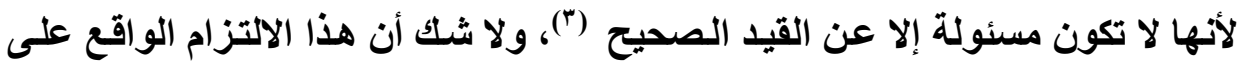
جهة التوثيق هو التزام ببذل العناية الكافية من أجل التحقق من صحة البيانـات وليس

(1) علاء حسين مطلق: الجهة المختصة بإصدار شهادات التوثيق الإكتروني ، مرجع سابق. (2) Jaccard (M). Op. Cit. P.3. ERRIC A.CAPRIOLI. Op. Cit. P.794.Eric (c): Le Juge et la prevue electronique. P, 19. 
د/ أشرف محمد إسماعيل

عدد خاص بالمؤتمر الدولى السنوى العشرون

التزام بتحقيق نتيجة ، ويترتب على هذا التكييف أنها لا مسئولية على تلكك الجهة عن عدم دقة البيانات ، متى بذلت في ذلك عناية كافية.

ثانياً: لاالتزام بإصدار شهادات التوثيث الإكتروني: الغاية من وجود جهات

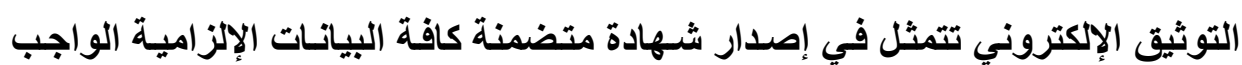
توافرهـا حسبما سبق بيانها ، ذلتك أن غايـة الأفراد مـن اللجوء للمعاملـة الإكترونيـة وتوثيقها بشكل تقني هو إسباغ طابع الثقة والأمان والسرية لدفع الغير من التعاقد معهم بعد التحقق من شخصيتهم وإرادتهم الجدية في التعاقد ، وذلك لا يتم إلا بإصدار شهادات

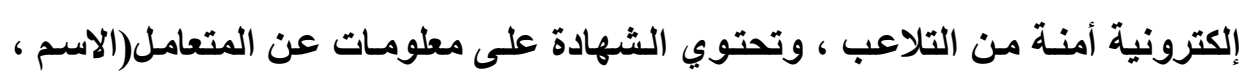
والعنوان ، واسـم مصدر الشهادة ، والمفتـاح العمـومي للمتعامل ، والرقم التسلسلي ، وتاريخ تسليم وإصدار الشهادة ، وتاريخ انتهاء صلاحيتها...).

وجـاء في تعريف شـهادة التوثيق الإكترونـي في المـادة(1) مس قـانون تنظيم

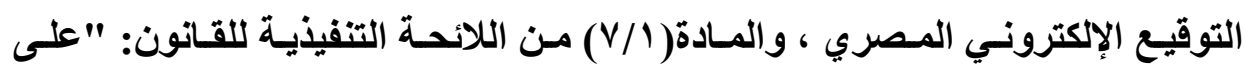
التزام جهة التوثيق بإصدار شهادات التوثيق الإكتروني ، وهي التي تصدر من الجهة

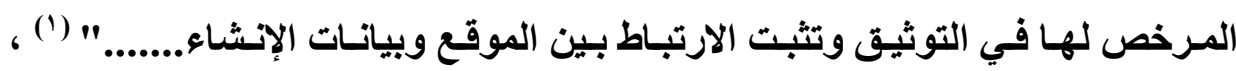
ويعتبر هذا الالتزام من التزامات تحقيق النتيجة.

ثالثًا: الالتزام بالمحافظة على سرية بيانات التوثيق: يُقصد بالسرية في هذا الثأن الحفاظ على البيانات ذات الطابع الثخصي من طالب الشهادة إلى جهة التوثيق لأن الإلكترونـي ، بهـدف حفظهـا أو تبادلهـا أو اسـتخدامها فـي تـأليف مفــتيح التوثيـق

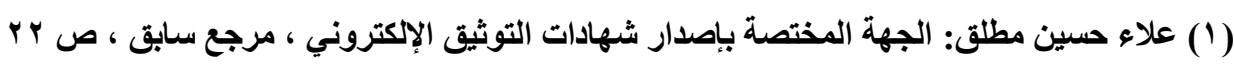
وما بعد ها.

مجلة البحوث القانونيت والإقتصاديت 
الإكترونسي وإصدار شهادة معتمدة في هذا الخصوص (')، حيث أن الأمسان والسرية

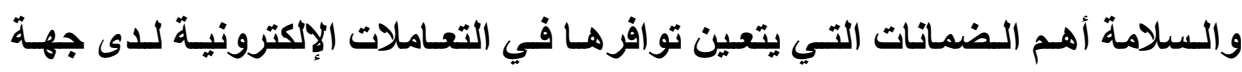

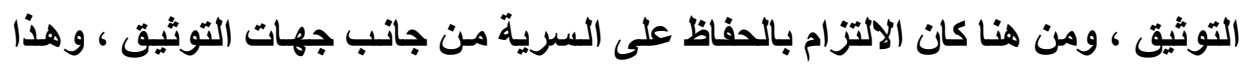

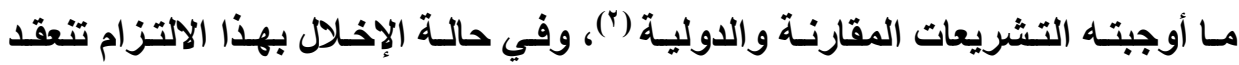
مسئولية جهة التوثيق تجاه صاحب الثهادة الإكترونية بثقيها المدنية والجنائية. وينبغي القول أن التثريعات المنظمة لعمل جهات التوثيق الإكتروني لم تفرق

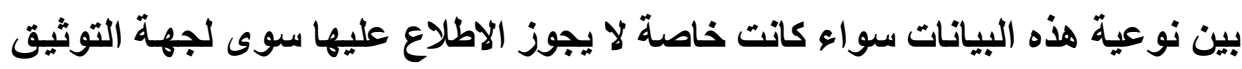

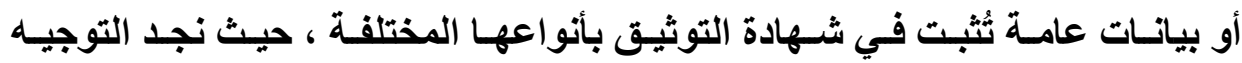

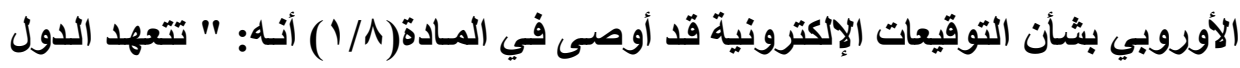

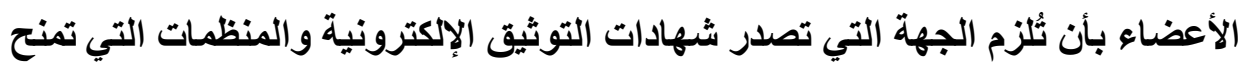

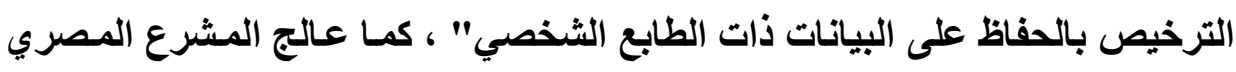

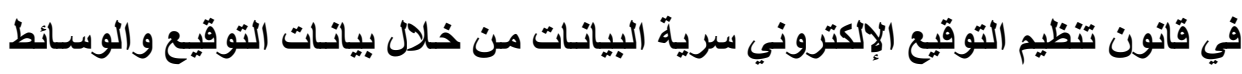

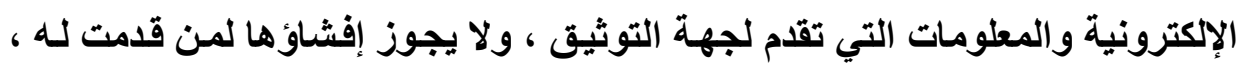

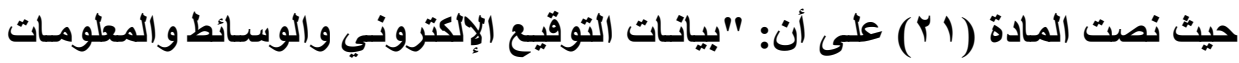

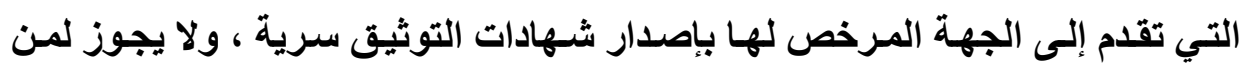

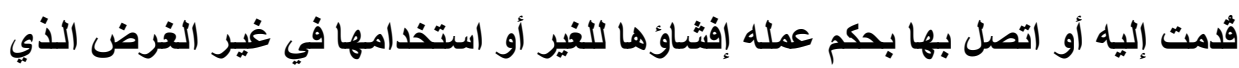

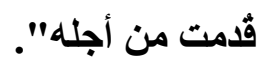

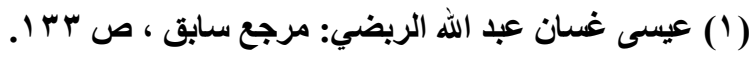

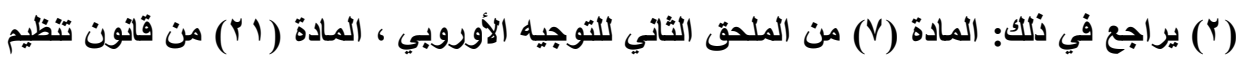

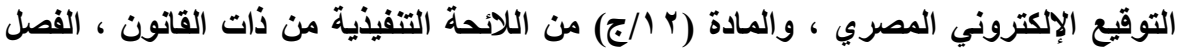
(0 1 ) من قانون المبادلات والتجارة الإكترونية التونسي. 
د/ أشرف محمد إسماعيل عدد خاص بالمؤتمر الدولى السنوى العشرون

يتبين من ذلك أن هذا الالتزام يُكسب التعامل الإكتروني الثقة والأمسان ، حيث لا

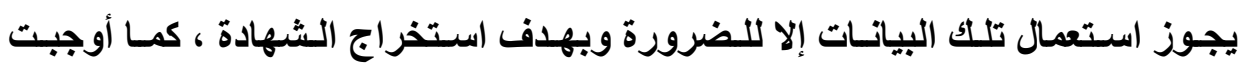
النصوص التشريعية على جهة التوثيق قبل كل معالجة للمعلومـات الثخصية إعلام

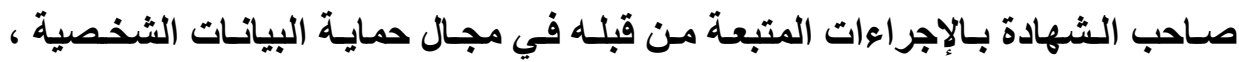

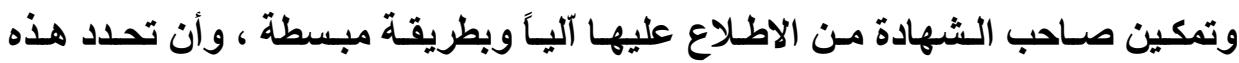
الإجراءات هوية المسئول عن المعالجة ، وطبيعة البيانات والغاية من المعالجـة ، الأمر

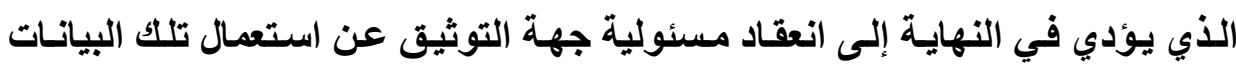

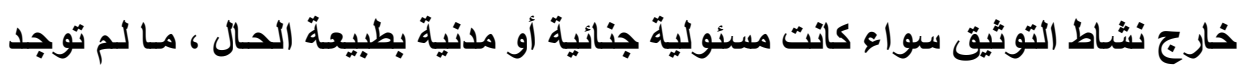
موافقة كتابية ( ) صريحة ومسبقة من طالب الشهادة.

ويلاحظ أن هذا الالتزام بسرية البيانات والمعلومات هو التزام ببذل عناية وليس تحقيق نتيجة ، إلا إذا ثبت العكس من قبل جهة التوثيق أنها قد تسببت عن عمد في إفشاء أسرار البيانات.

رابعـاً: الالتزام بوقف الشهادة الإكترونيـة مؤقتـاً أو إلغائهـا: تلتزم جهـة

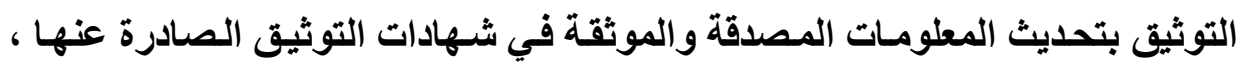
وتوقف الثهادة الإكترونية مؤقتاً أو تلغيها إذا توافر سبب يوجب ذلتك بنـاءً على طلب

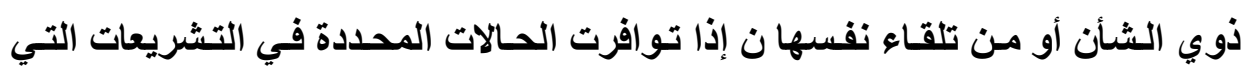

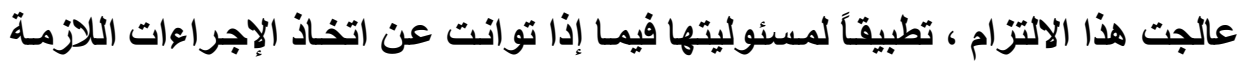

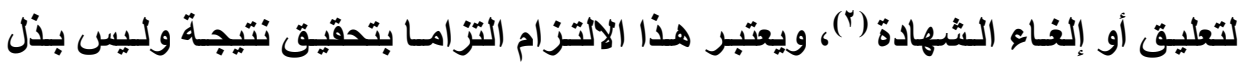
العناية.

(1) Didier, Gobert, Cadre, juridique pour les signatures electronique et les services de certification, pree. P. 18.

(ץ) علاء حسين مطلق: الجهة المختصة بإصدار شهادات التوثيق الإكتروني ، مرجع سابق ، ص اه 18 
فقد يتضح لجهـة التوثيق وجود تغيير جوهري في بيانـات شهـادة التوثيق الإكتروني ، مثل علمها بتزوير الوثائق المقدمة لها من أصحاب العلاقة أو تبين للجهة

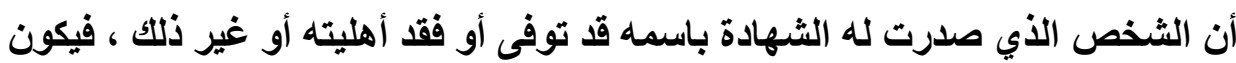

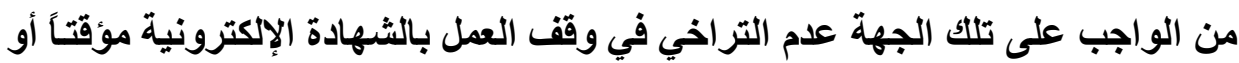
إلغاؤها إلغاءاً كاملاً ، حيث أن الإخلال بهذا الالتزام قد تترتب عليه أثار خطيرة وخاصة التها

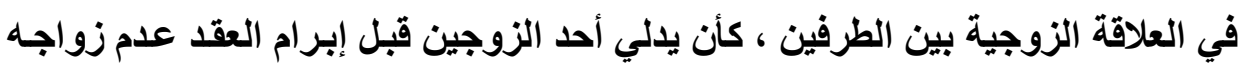

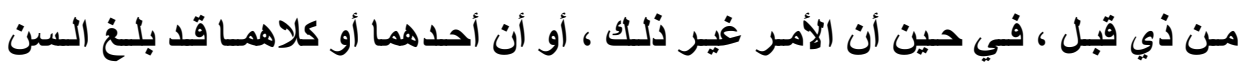
القانوني للزواج ، في حين أنه دون السن المقرر ، الأمر الأي يمثل غشاً وينشأ علاقة

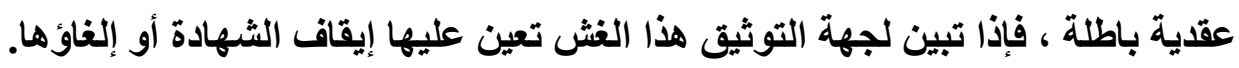
وترتيباً على ذلك ، نصت التشريعات الدولية على هذا الالتزام نظراً لأهميته ،

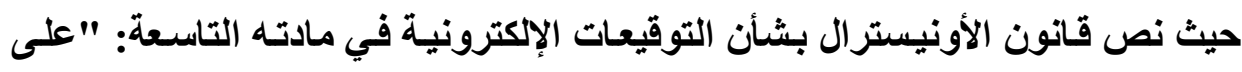

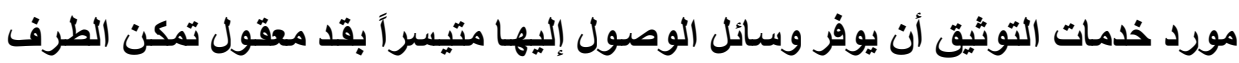
المرتكن من التأكد عند الاقتضاء من الثهادة أو سواها.....الخ". وتجدر الإثـارة إلى أن المسشرع المصري لـم يُعـالج حساتات التعليق والإلغـاء

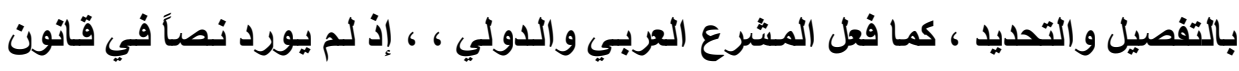

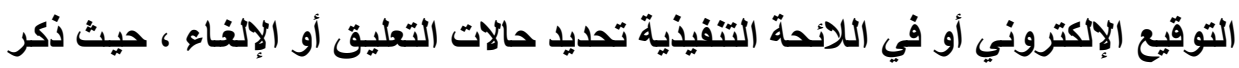

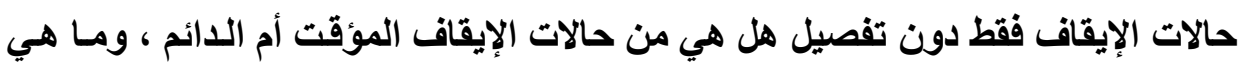

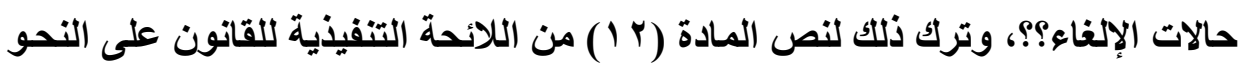

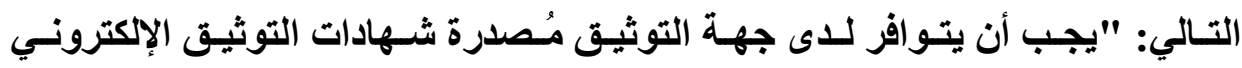

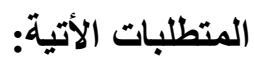


• نظام لتحديد تـاريخ ووقت إصدار الشهادات وإيقافها ، وتعليقها ، وإعـادة

تشغيلها ، و إلغائها.

• نظام لإيقاف الثهادة في حالة ثبوت العبث ببياناتها أو تغيير في محتواهـا أو

انتهاء صلاحيتها.

ولا شــك أن عـدم قيـام المشرع المـصري بتحديـــ حسالات وقف و إلغــاء الـشهادة الإكترونية على وجه الدقة ، يُعد نقصاً تشريعياً يستوجب تداركه (")، وبـالرجوع لبعض التشريعات العربية التي نصت على حالات إيقاف الثهادة الإكترونية ، نجد من بينها على سبيل المثال لا العصر أن المشرع العُماني نص في المادة (؟ب) من قانون المعاملات الإكترونية: "على مقدم خدمات التوثيق تعليق العمل بالشهادة فوراً بناءً على طلب صاحبها أو إذا تبين لـه أو كـان هنـاك مـا يحمله على الاعتقاد

• الشهادة قد سُلمت بناءًُ على معلومات خاطئة أو مزيفة. • الشهادة قد استخدمت لأغراض التدليس. • المعلومات المُضمنة في الشهادة قد تغيرت. • أداة التوقيع كاتت مُنتهكة.

على أن يتم إبـلاغ صـاحب أو أصحاب الشهادة الإكترونية على الفور عند تعليق

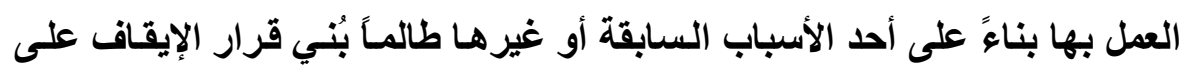

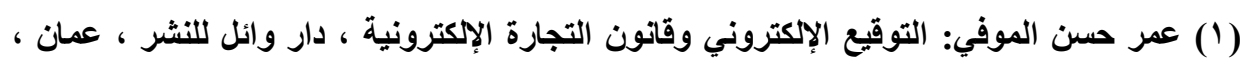

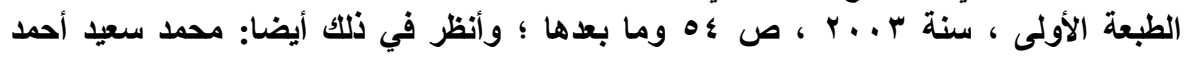

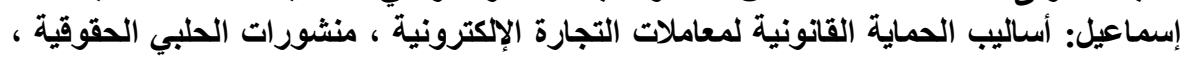

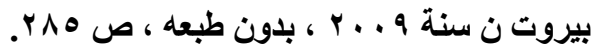


د/ أشرف محمد إسماعيل عدد خاص بالمؤتمر الدولى السنوى العشرون

مبرر مشروع ، ذلك أن الشهادة بمجرد صدورها والتوثيق عليها يتعلق بها حقاً للغير (')، مما يترتب عليه ضرورة الإخطار درعاً للمسئولية أو المطالبة بالتعويض.

\section{الفرع الثاني: المسئولية المدنية لجهة التوثيق الإلكتزونية}

لم ينص المشرع المصري في قانون تنظيم التوقيع الإكترونـي وإنشاء هيئة تنمية صناعة تكنولوجيا المعلومـات أو اللائحة التنفيذية على مسئولية جهة التوثيق الإكتروني ، وبالتالي فإنها تخضع للقواعد العامـة للمسئولية المدنية استناداً للمسادتين

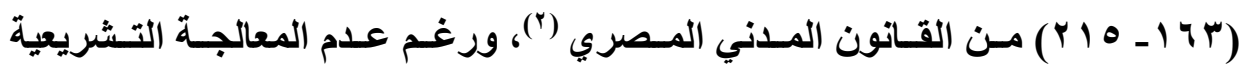
الصريحة لتلـك المسئولية الناجمـة عن إخـلال جهـة التوثيق الإكترونـي بالتزاماتهـا القانونيـة ، إلا أن المشرع المصري نظم عمليـة مزاولـة نشاط التوثيق الإكترونسي ، وأنشأ هيئة مختصة بـلكل ، هي هيئة صناعة تكنولوجيا المعلومـات ، كمـا بين أيضا أهداف تلك الهيئة واختصاصها ، وكيفية إداراتها ، وخدماتها المختلفة ، وكافة أعمالها. وأكدت المـادة (9 1) من قـانون تنظيم التوقيع الإكترونسي المصري على عدم جواز مزاولة نشاط إصدار شـهادات التوثيق الإلكتروني إلا وفق الإجراعات والقواعد

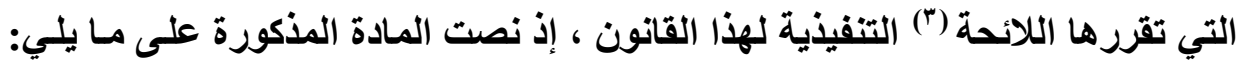
"لا تجوز مزاولـة نشاط إصدار شـهادات التوثيق الإكترونـي إلا بترخيص من الهيئة

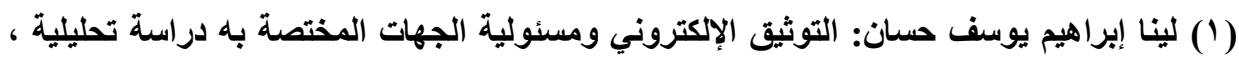

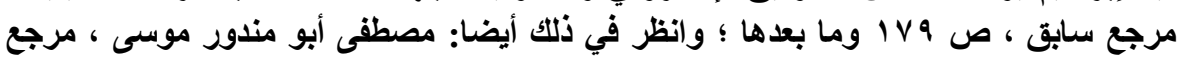

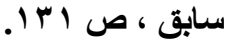
(r) ايمان مأمون أحمد سليمان: ابرام العقد الإكتروني وإثباته ، دار الجامعة الجديدة للنشر ، سنة

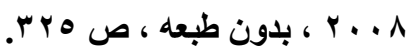

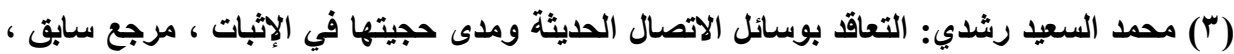


نظير مقابل يحده مجلس إدارتها وفقاً للإجراعات والقواعد والضمانات التي تقررهـا

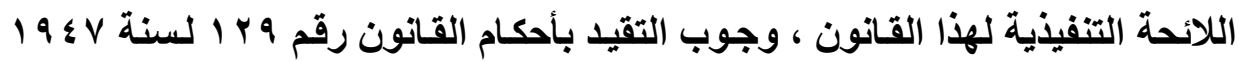
بالتزامات المرافق العامة.........

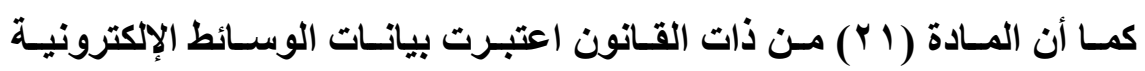
والتوقيعـات الإكترونيـة والتـي تقدم لجهـة التوثيتق ، هـي بيانـات سـرية ، ولا يجـوز

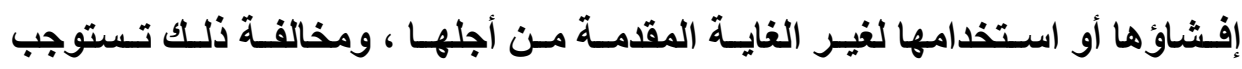
المسئولية الجنائية والمدنية ، والتي جاء نصُها كالتـالي: "بيانـات التوقيع الإكترونسي والوسائط والمعلومات الإكترونية التي تقدم إلى الجهة المرخص لهـا بإصدار شـهادات التوثيق الإكتروني سرية ، ولا يجوز لمن قدمت إليه أو اتصل بها بحكم عمله إفشاؤها

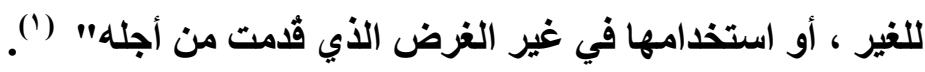
ونجد المادة (YrT) من القانون المذكور أفردت عقوبـات جنائية وغرامـات مالية بحق كل من خالف أحكام المادتين 9 او ا ب المذكورتين أعلاه أو بحق من قدام بإصدار شهادات التوثيق دون الحصول على الترخيص اللازم لهذا العمل. كما عالجت اللائحة التنفيذية التزامات جهة التوثيق الإكترونسي ، ومنها التعاقد حسب النمـوذج المعد مسن قبـل هيئة تنميـة صـنـاعة تكنولوجيـا المعلومسات ، وتقديم ضمانات وتأمينـات لتغطية أيسة أضرار أو أخطار قد تلحق بذوي الشأن جراء إصدار شهادات إلكترونية ، وعند الاطلاع على كراسـة شروط ومتطلبات منح تراخيص تقديم الخدمات الإكترونيـة الصادرة عن هيئة تنمية صناعة تكنولوجيـا المعلومـات السلطة المختصة في التشريع المصري ، نلاحظ أن المشرع بين كافة الاشتراطات في كراسـة 
الثروط لمعرفة طبيعة الالتزامات والمسئولية الناشئة عن عدم مراعـاة أو مخالفة هذه الالتزامات (')، لا سيما وأن قانون تنظيم التوقيع الإكتروني واللائحة التنفيذية قد أحالاً تفاصيل الاثتر اطات إلى هذه الكراسة والعقد النموذجي المُعد من قبل السلطة المختصة. وحيث أن الثابت فقهاً وقضاعاً بـأن مسئولية جهة التوثيق تكون تعاقديـة أمسام صـاحب الشهادة وتقصيرية أمسام الغير ، إلا أنتـا نلاحظ المشرع المصري قد أضـاف مسئولية لجهة التوثيق تجـاه هيئة تنمية صناعة تكنولوجيا المعلومـات ، بحيث تكون

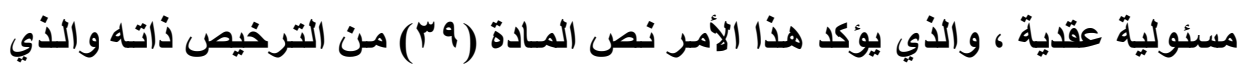
جـاء مـن ضـمنها مـا يلـي: فيمـا يتعلق بمسئولية جهة التوثيق تجـاه مستخدم الخدمـة الراغب في الاستفادة مـن خدمات التوثيق الإلكترونسي ومـن بينهـا شـهادات التوثيق الإكترونيـة ، فإنـهـ نظراً لوجـود نمـوذج تعاقـ مُعـد مسبقاً مسن قبـل الجهـة المختصة والمسمى بعقد تقديم خدمات إلكترونية ، فإن وجود هذا العقد والموقع بين جهة التوثيق كطرف أول ومستخدم الخدمسة كطرف ثـان ، يجعل مـن مسئولية جهـة التوثيق عنــ

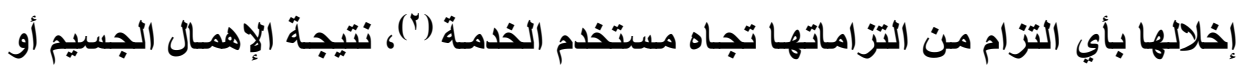
تعدد الإهمال مسئولية عقدية ، وقد تم التأكيد على هذا الأمر بموجب المـادة (^) من العقد وتحت عنـوان "المسئوليات القانونيـة"، إذ نـصت الفقرة الأخيرة مـن المـادة المذكورة على ما يلي: "يكون مقدم الخدمـة الإكترونية مسئولاً قانونـاً عن أي إهمال جسيم أو تعمد الإهمال".

(1) هلى حامد قثقوش: الحماية الجنائية للتجارة الإكترونية عبر الإنترنت ، دار النهضة العربية ،

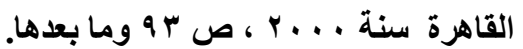

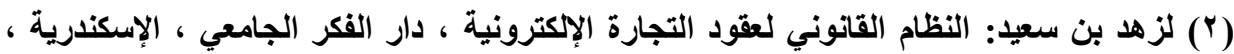

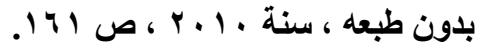

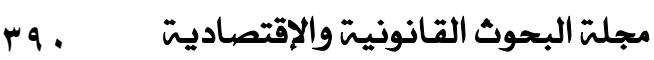


وأخيراً تنص المادة (9) من نموذج التعاقد المُعد مسبقاً من قبل الجهة المختصة

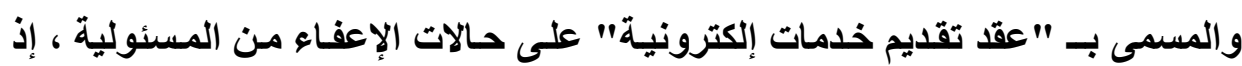

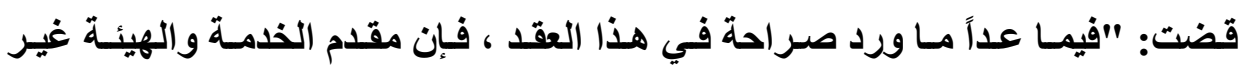

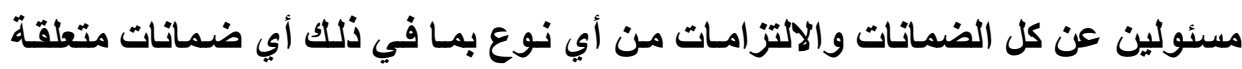

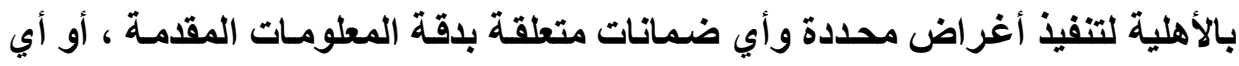

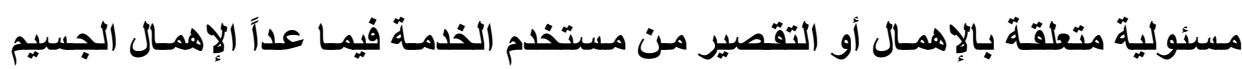

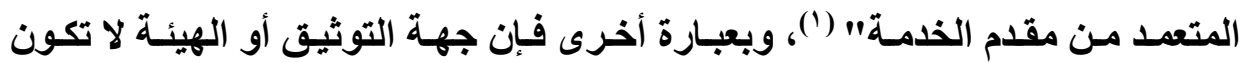

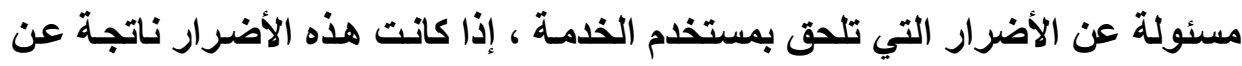
إهماله أو تقصيره درعاً لأية أخطار قد يتعرض لها نتيجة استعمال شهادات التوثيق. وتجدر الإثـارة إلى أن التوجيه الأوروبي بثأن التوقيعات الإكترونيـة لسنة

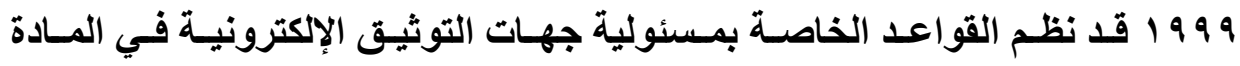
السادسة منه ، إلا أنه لم ينظم سوى قواعد المسئولية الخاصة بجهات التوثيق المعتمدة

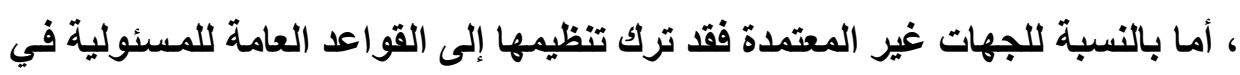
قو انين الدول الاعضاء ، وأعطى للتوقيع الإكتروني ذات الحجية التي يتمتع بها التوقيع

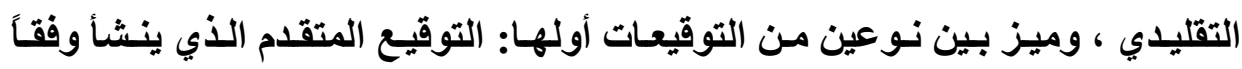

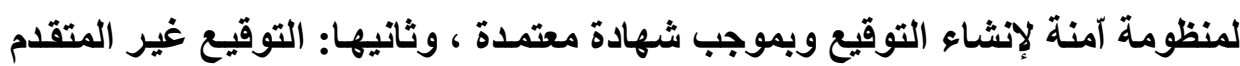

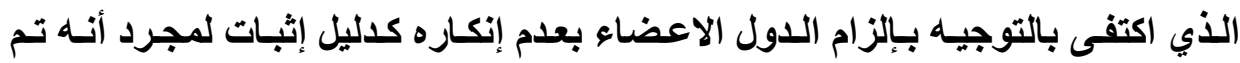

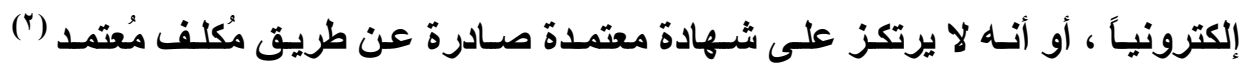

(1) محمد سعيد أحمد إسماعيل: أساليب الحماية القانونية لمعاملات التجارة الإكترونية ، مرجع

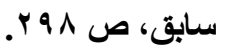
(ץ) عمر حسن الموفي: التوقيع الإكتروني وقانون التجارة الإكترونية ، مرجع سابق ، ص ب • r. 
عدد خاص بالمؤتمر الدولى السنوى العشرون أشرف محمد إسماعيل

بخدمة التوثيق ، أو أنه لم ينشأ وفقاً لمنظومة آمنة ، ويلاحظ أن تنظيم المسئولية لتلك الجهات وفقاً للتوجيه الأوروبي يقوم على قاعدتين أساسيتين هما: • المسئولية المفترضة لجهات التوثيق الإكترونية: حيث تنعقد مسئوليتها تلقائياً بمجرد ثبوت مخالفات تمس صحة البيانـات المتضمنة في الشهادة المُعتمدة ، ما لم تُثبت جهة التوثيق أنها لم تُهمل ولم ترتكب خطاً في أداء مهمتها.

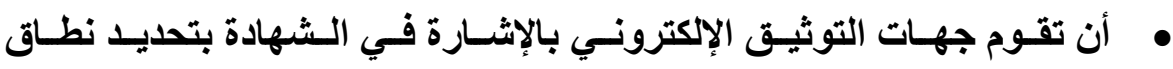

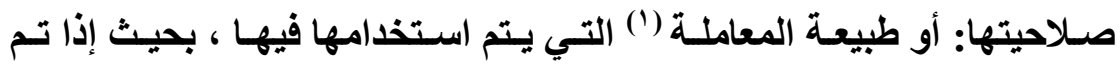
تجاوز هذا النطاق لا يمكن مسائلة جهة التوثيق عن هذا التجاوز بأي شكل من

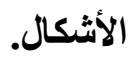




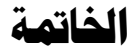

أثار التقدم الهائل في تكنولوجيا المعلومـات في عالمنـا الحديث ثُورة هائلة في

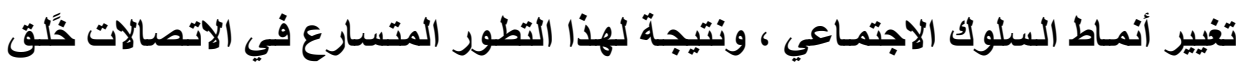
عالمـاً جديداً يعتمــ على الشبكات الرقميـة التي تعمل على نقل المعلومـات والبيانـات

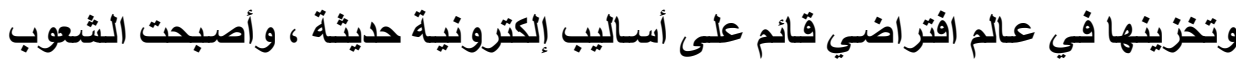
تتحاور فيما بينها دون قيود ، وانتقل ذلك تدريجياً من تغيير شكل كافة العقود المبرمسة بين الأفراد من الثكل التقليدي أو اليدوي إلى الثكل الإلكترونسي أو اللامسادي وكان من كن

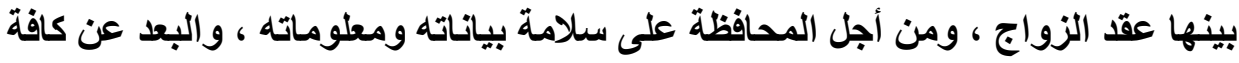

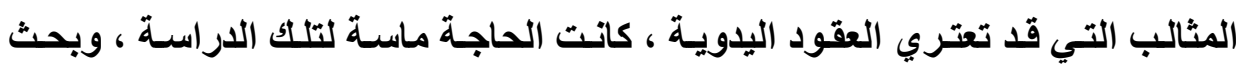

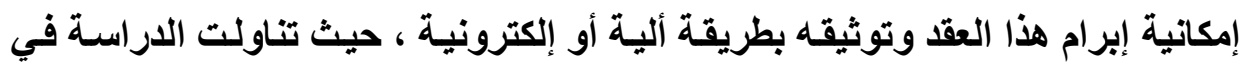
المطلب الأول: المفهوم القانوني والفقهي للتوثيق الإلكتروني وأثر ذلتك على تغيير نمط

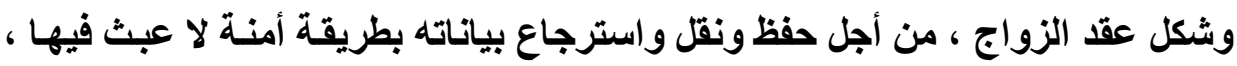
وجاء المطلب الثاني: في هذه الدراسة لبحث التزامسات جهة التوثيق بوصفها مُصدئ لثهادات وعقود إلكترونية مع التعرف عن كثب على طبيعة المسئولية المدنية لجهة

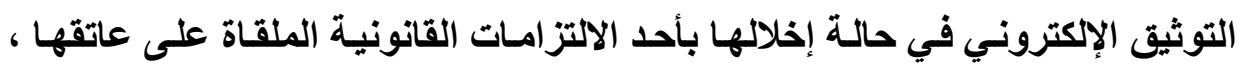
وتوصلت الاراسة في النهاية لعدة نتائج وتوصيات كان من أبرزها:-

(النتائج):- (ائ)

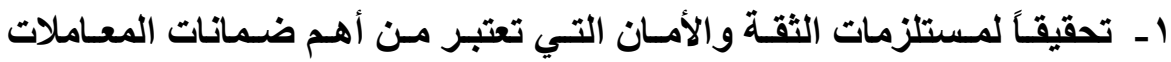
الإكترونية ، ظهرت الحاجة ملحة لوجود طرف ثالث مستقل عن طرفي العلاقة العقدية ، يمكن تسميته بجهة التوثيق الإكتروني. 


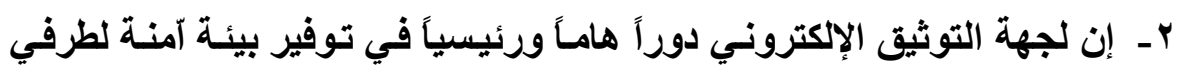

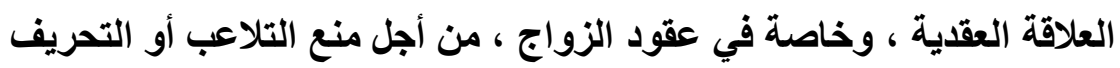

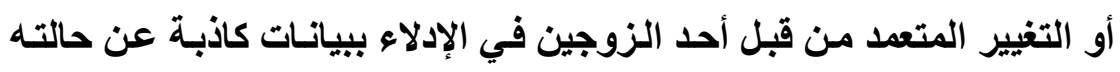
ومعلوماته الثخصية ، بقصد تضليل الطرف الأخر ، أو الإضرار بحقوق الغير.

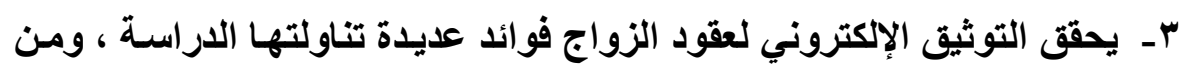

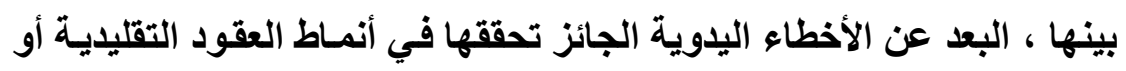
المادية ، وحفظ حقوق طرفي العلاقة العقدية ، وإمكانية حفظواسترجاع ونقل الإنل كافة البيانات الشخصية بطريقة مؤمنة إلكترونياً.

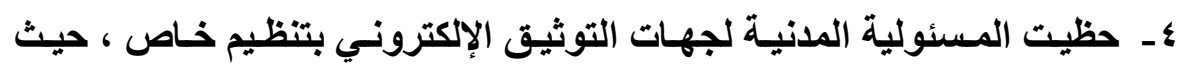

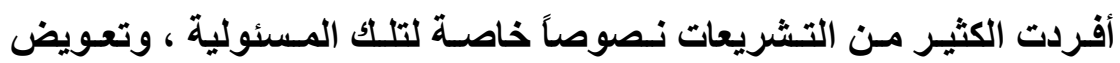
الأضـرار الناتجـة عن إخلالهـا بالتزاماتها ، ومـن هذه التشريعات التوجيـها

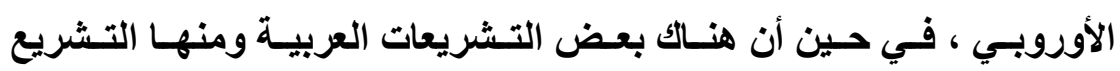

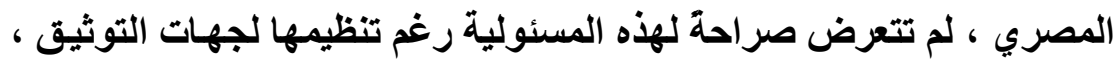

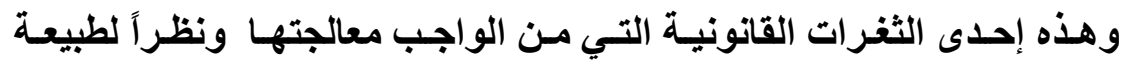

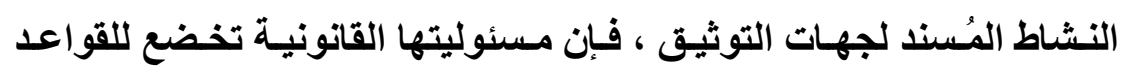

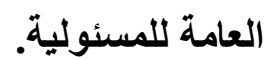
(التوصيات):- (الت

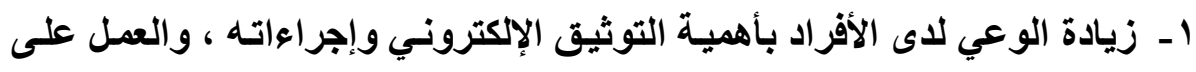
توفير سبل ووسائل تقنية حديثة لاى كافة الإدارات والمر افق الحكومية.

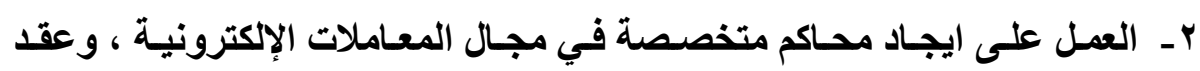

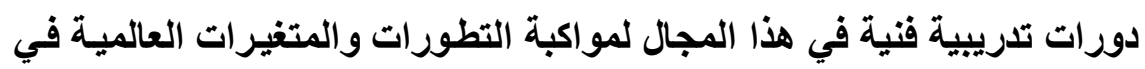

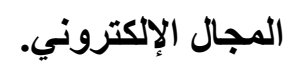




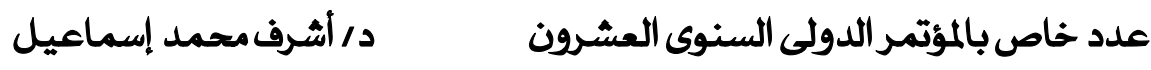

ץ- ضرورة تعميم الوثائق الإكترونية في عقود الزواج على المستوى الإقليمي ،

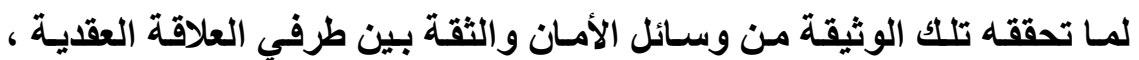
و البعد عن أفعال التغيير أو التعديل أو التحريف التي ترد في الوثثائق التقليدية

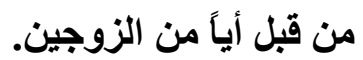

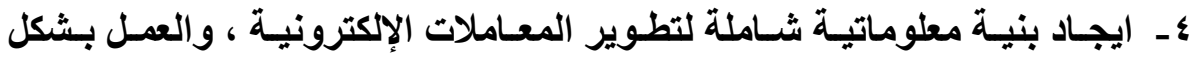
مستمر على حفظ ونقل واسترجاع ومعالجة كافة البيانات والمعلومات الثخصية بطريقة ألية وتكنولوجية أمنة. قائمة المراجع والمادر أولاً: المراجع العامة:

1.إبراهيم الدسوقي أبو الليل: الجوانب القانونيـة للتعـاملات الإكترونيـة ، دار

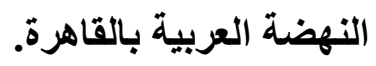

r.أحمد الجندي: مبادئ القضاء في الأحوال الثخصية ، دار الكتب القانونية ، سنة

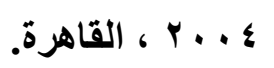

r.أحمد الغندور: الأحوال الثخصية ، مكتبة الفلاح للطباعة والنشر، بدون سنة

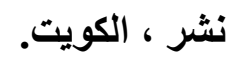

؛ُ.ايمان مأمون أحمد سليمان: ابرام العقد الإكتروني و إثباته ، دار الجامعة الجديدة

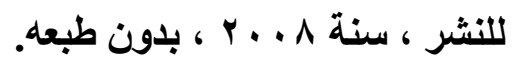

ه.سالم الرافعي: أحكام الأحوال الشخصية للمسلمين في الغرب ، دار بن حزم للنشر

، بيروت ، الطبعة الأولى ، بدون سنة نشر. 
د/ أشرف محمد إسماعيل عدد خاص بالمؤتمر الدولى السنوى العشرون

7.عمر حسن المـوفي: التوقيع الإكترونـي وقـانون التجـارة الإكترونيـة ، دار وائل

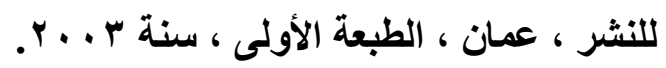

V.علاء حسين مطلق التميمي: الأرشيف الإكتروني ، دار النهضة العربية ، القاهرة

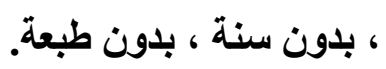

^.عبير ميخائيل الصفدي: النظام القانوني لجهات التوثيق والتوقيع الإكتروني ، دار

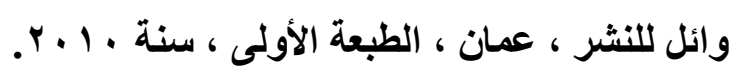

9.عيسى غسان عبد الله الربضي: القواعد الخاصـة بـالتوقيع الإكترونس ، جامعة جرش الخاصة ، رسالة دكتوراه ، جامعة عين شمس ، القاهرة ، سنة و ، . . . . • ا.علاء حسين مطلق التميمي: الاليل الإكتروني في الإثبات المدني ، دار النهضة

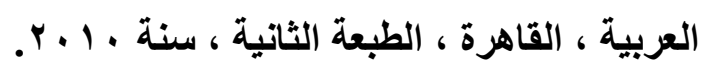

11 (محمد فوزي فيض الله: الزواج وموجباته في الشريعة الإسـلامية ، مكتبة المنـار الإسلامية ، بدون سنة نشر ، الكويت.

r ا مصطفي أبو مندور موسى: الجوانب القانونية لخدمات التوثيق الإكتروني ، دار

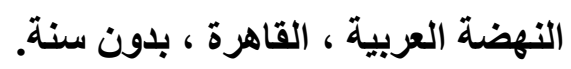

r ا .محمد السعيد رشدي: التعاقد بوسائل الاتصال الحديثة ومدى حجيتها في الإثبات

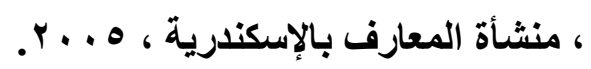

؛ ا .محمد حسين منصور: الإثبات التقليدي والإكترونـي ، دار الجامعة الجديدة ،

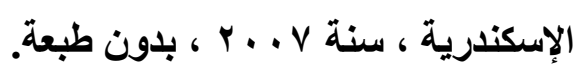

ه امحمد فوزي فيض الله: الزواج وموجباته في الشريعة الإسلامية ، مرجع سابق؛ ومؤلفه أيضا: الإلمام بأصول الأحكام ، دار التقلم ، سنة 9 ، 9 1 ، الكويت. 
د/ أشرف محمد إسماعيل عدد خاص بالمؤتمر الدولى السنوى العشرون

19 .محمـد سـعيد أحمــ إسـماعيل: أسـاليب الحمايـة القانونيـة لمعـاملات التجـارة الإكترونية ، منشورات الحلبي الحقوقية ، بيروت ، سنة و ، . + ، باون طبعه.

V ا.نضال إسماعيل إبراهيم: أحكام عقود التجارة الإكترونية ، دار الثقافة للنشر

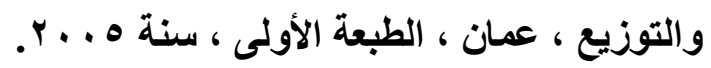

1 1 الينا إبراهيم يوسف حسان: التوثيق الإلكتروني ومسئولية الجهات المختصة بـه دراسة تحليلية ، دار الراية للنشر والتوزيع ، عمان ، سنة و ، . ؟.

9 1.لزهد بن سعيد: النظام القانوني لعقود التجارة الإلكترونية ، دار الفكر الجامعي ،

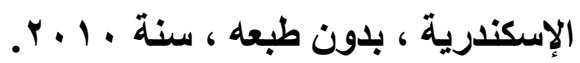

• . . هدى حامد قشقوش: الحمايـة الجنائيسة للتجـارة الإكترونيـة عبر الإنترنت ، دار .

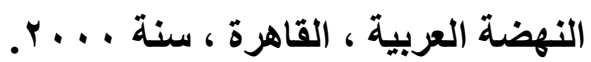
ثانياً: المراجع والمواقع الأجنبية:

1-A Michal Froom Kin, The Essential Role of Third Trusted Parties in Electronic, Commerce, Buffialo Law Journal, 1996 At 2-11.

2-Article 2:"(e) Certification service provider means a person that issue certificates and may provid other services related to electronic signatures".

3- Didier, Gobert, Cadre, juridique pour les signatures electronique et les services de certification, pree. P. 18. 
د/ أشرف محمد إسماعيل عدد خاص بالمؤتمر الدولى السنوى العشرون

4-Thierry Piette-Coudol, $<$ Certification electronique: pratique et modelisation>, http:llwww.e-betobe.coml texteece, htm.

5- Jaccard (M). Op. Cit. P.3. ERRIC A.CAPRIOLI. Op. Cit. P.794.Eric (c): Le Juge et la prevue electronique. P, 19.

ثالثاً: القوانين الدولية والتشريعات المقارنة:-

1. قانون الأونيسترال النموذجي الخاص بالمعاملات رقم ه1 لسنة 999 19.

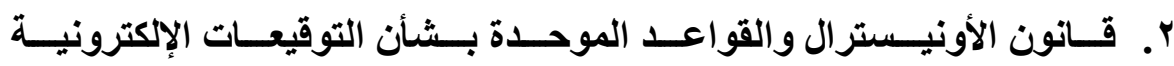

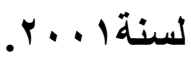
ץ. قواعد التوجيه الأوروبي لسنة ..... ؛. قانون الأحوال الثخصية المصري رقم(1) لسنة .... †.

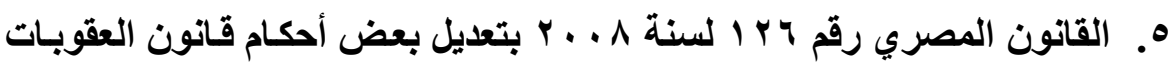

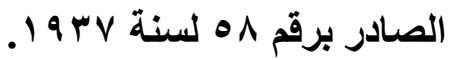

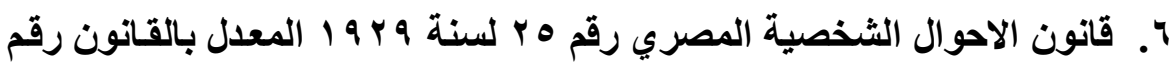

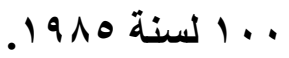

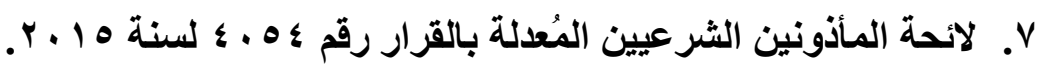

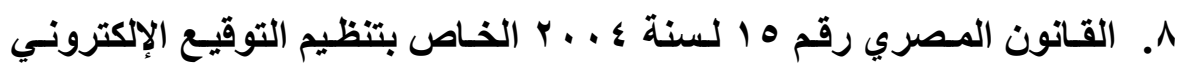
والمعاملات الإكترونية.

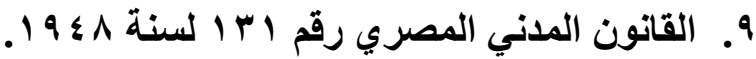

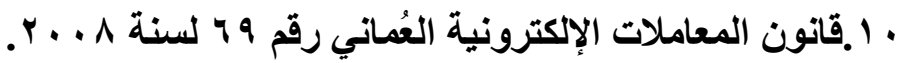

1 1. المذكرة الإيضاحية لقانون الأحوال الثخصية الكويتي رقم( (ه) لسنة ؛ 191. 